\title{
The role of serotonin $5-\mathrm{HT}_{2 \mathrm{~A}}$ receptors in memory and cognition
}

\author{
Gongliang Zhang ${ }^{1,2,3 *}$ and Robert W. Stackman Jr.,4* \\ ${ }^{1}$ College of Basic Medicine, Anhui Medical University, Hefei, China, ${ }^{2}$ Department of Biology, Charles E. Schmidt College of \\ Science, Florida Atlantic University, Jupiter, FL, USA, ${ }^{3}$ Jupiter Life Science Initiative, Florida Atlantic University, Jupiter, FL, \\ USA, ${ }^{4}$ Department of Psychology, Charles E. Schmidt College of Science, Florida Atlantic University, Jupiter, FL, USA
}

\section{OPEN ACCESS}

Edited by:

Alfredo Meneses,

Center for Research and Advanced

Studies, Mexico

Reviewed by:

Maria Antonietta De Luca,

University of Cagliari, Italy

Giuseppe Di Giovanni,

University of Malta, Malta

${ }^{*}$ Correspondence:

Gongliang Zhang,

College of Basic Medicine, Anhui Medical University, 81 Meishan Road,

Hefei, Anhui 230032, China gzhang@fau.edu;

Robert W. Stackman Jr.

Department of Psychology,

Charles E. Schmidt College

of Science and Jupiter Life Science Initiative, Florida Atlantic University,

MC-19(RE), Room 101,

5353 Parkside Drive, Jupiter,

FL 33458, USA

rstackma@fau.edu

Specialty section:

This article was submitted to

Neuropharmacology,

a section of the journal

Frontiers in Pharmacology

Received: 02 July 2015

Accepted: 22 September 2015

Published: 06 October 2015

Citation

Zhang G and Stackman RW Jr. (2015)

The role of serotonin $5-H T_{2 A}$

receptors in memory and cognition.

Front. Pharmacol. 6:225.

doi: 10.3389/fphar.2015.00225
Serotonin 5- $\mathrm{HT}_{2 \mathrm{~A}}$ receptors $\left(5-\mathrm{HT}_{2 \mathrm{~A}} \mathrm{Rs}\right)$ are widely distributed in the central nervous system, especially in brain region essential for learning and cognition. In addition to endogenous 5-HT, several hallucinogens, antipsychotics, and antidepressants function by targeting $5-\mathrm{HT}_{2 \mathrm{~A}} \mathrm{Rs}$. Preclinical studies show that $5-\mathrm{HT}_{2 \mathrm{~A}} \mathrm{R}$ antagonists have antipsychotic and antidepressant properties, whereas agonist ligands possess cognition-enhancing and hallucinogenic properties. Abnormal $5-H_{2 A} R$ activity is associated with a number of psychiatric disorders and conditions, including depression, schizophrenia, and drug addiction. In addition to its traditional activity as a $\mathrm{G}$ proteincoupled receptor (GPCR), recent studies have defined novel operations of $5-\mathrm{HT}_{2 \mathrm{~A}} \mathrm{Rs}$. Here we review progress in the (1) receptor anatomy and biology: distribution, signaling, polymerization and allosteric modulation; and (2) receptor functions: learning and memory, hallucination and spatial cognition, and mental disorders. Based on the recent progress in basic research on the $5-\mathrm{HT}_{2 \mathrm{~A}} \mathrm{R}$, it appears that post-training $5-\mathrm{HT}_{2 \mathrm{~A}} \mathrm{R}$ activation enhances non-spatial memory consolidation, while pre-training $5-\mathrm{HT}_{2 \mathrm{~A}} \mathrm{R}$ activation facilitates fear extinction. Further, the potential influence that $5-\mathrm{HT}_{2 \mathrm{~A}} \mathrm{R}$-elicited visual hallucinations may have on visual cue (i.e., landmark) guided spatial cognition is discussed. We conclude that the development of selective $5-\mathrm{HT}_{2 \mathrm{~A}} \mathrm{R}$ modulators to target distinct signaling pathways and neural circuits represents a new possibility for treating emotional, neuropsychiatric, and neurodegenerative disorders.

\section{Keywords: serotonin, $5-\mathrm{HT}_{2 \mathrm{~A}}$ receptor, learning, memory, cognition}

\section{Introduction}

The serotonin (5-HT) 5- $\mathrm{HT}_{2 \mathrm{~A}}$ receptor $\left(5-\mathrm{HT}_{2 \mathrm{~A}} \mathrm{R}\right)$ is a GPCR of the type A family. It was defined as the classical D receptor initially by Gaddum and Picarelli (1957), and later referred as the 5- $\mathrm{HT}_{2}$ receptor by Peroutka and Snyder (1979). The $5-\mathrm{HT}_{2 \mathrm{~A}} \mathrm{R}$ gene is located on human chromosome 13q14-q21. HTR2A gene codes for a 471-amino acid sequence in rat, mouse, and human

Abbreviations: 5-HT, 5-hydroxytryptamine/serotonin; AD, Alzheimer disease; AMPAR, alpha-amino-3-hydroxy-5-methyl4-isoxazole propionate receptor; BLA, basolateral amygdala; CS, conditioned stimulus; DOI, 1-(2,5-dimethoxy-4iodophenyl)-2-aminopropane; ERK, extracellular signal-regulated kinases; GFAP, glial fibrillary acidic protein; GPCR, G protein-coupled receptor; IP; inositol phosphate; LSD; lysergic acid diethylamide; mGluR2, metabotropic glutamate receptor; MUPP1, multiple PDZ protein-1; MWM, Morris water maze; NAc, nucleus accumbens; NMDAR, $N$-methyl-D-aspartate receptor; NOR, novel object recognition; OCD, obsessive-compulsive disorder; PDZ, postsynaptic density zone; PFC, prefrontal cortex; PKC, protein kinase C; PLC, phospholipase C; PSD, postsynaptic density; RSK2, ribosomal S6 kinase 2; sIPSC, spontaneous inhibitory postsynaptic current; sIPSP, spontaneous inhibitory postsynaptic potential; US, unconditioned stimulus. 
(Sparkes et al., 1991). The rat $5-\mathrm{HT}_{2 \mathrm{~A}} \mathrm{R}$ was cloned in 1988 (Pritchett et al., 1988) and the human 5- $\mathrm{HT}_{2 \mathrm{~A}} \mathrm{R}$ was reported by Julius et al. (1990). Central $5-\mathrm{HT}_{2 \mathrm{~A}} \mathrm{Rs}$ exert diverse behavioral, physiological, and psychological influences (Hoyer et al., 2002; Hannon and Hoyer, 2008; Homberg, 2012). Abnormality in the structure and function of the $5-\mathrm{HT}_{2 \mathrm{~A}} \mathrm{R}$ is associated with a number of disorders, including schizophrenia, depression/anxiety, and drug addiction. Furthermore, many hallucinogenic drugs exert their psychoactive effects by acting as agonists for $5-\mathrm{HT}_{2 \mathrm{~A}}$ Rs. Preclinical studies show that $5-\mathrm{HT}_{2 \mathrm{~A}} \mathrm{R}$ blockade has antipsychotic (Meltzer, 1999), antidepressant (Kroeze and Roth, 1998; Roth et al., 1998) and anxiolytic properties (Cohen, 2005). Pharmacological studies indicate that high-affinity antagonists of $5-\mathrm{HT}_{2 \mathrm{~A}} \mathrm{Rs}$ are effective atypical antipsychotics, due to their demonstrated efficacy to reduce both positive and negative symptoms of schizophrenia. Results from recent molecular biological and neuropharmacological studies suggest some exciting potential new avenues by which $5-\mathrm{HT}_{2 \mathrm{~A}} \mathrm{Rs}$ influence CNS function. Here we review progress in understanding the contribution of $5-\mathrm{HT}_{2 \mathrm{~A}} \mathrm{Rs}$ to modulation of learning and memory through an analysis of their (1) anatomy and biology: distribution, signaling, polymerization, and allosteric modulation; and (2) functions: learning and memory, hallucination and spatial cognition, and mental disorders. Based on the recent progress in $5-\mathrm{HT}_{2 \mathrm{~A}} \mathrm{R}$ research, we suggest that selective $5-\mathrm{HT}_{2 \mathrm{~A}} \mathrm{R}$ modulators targeting distinct signaling pathways may hold significant efficacy as new therapeutic approaches for several neurological disorders that present with cognitive impairment.

\section{5-HT $2 \mathrm{~A} R$ Anatomy and Biology in CNS}

\section{Cellular and Subcellular Distribution}

Serotonin $5-\mathrm{HT}_{2 \mathrm{~A}} \mathrm{Rs}$ are widely distributed in the CNS. In the rat brain, immunohistochemical studies show that $5-\mathrm{HT}_{2 \mathrm{~A}} \mathrm{Rs}$ are broadly expressed in the cerebral cortex - especially in layers $\mathrm{I}$ and $\mathrm{IV}-\mathrm{V}$, the piriform and entorhinal cortex, the claustrum, endopiriform nucleus, and olfactory bulb/anterior olfactory nucleus, brainstem, as well as the limbic system and the basal ganglia; especially in the NAc and caudate nucleus ( $\mathrm{Xu}$ and Pandey, 2000; Hannon and Hoyer, 2008). Interestingly, 5- $\mathrm{HT}_{2 \mathrm{~A}} \mathrm{R}$ binding appears to be absent from cerebellum ( $\mathrm{Xu}$ and Pandey, 2000).

In human brain, autoradiographic analysis using $\left[{ }^{3} \mathrm{H}\right]$ ketanserin indicates a high density of $5-\mathrm{HT}_{2 \mathrm{~A}} \mathrm{R}$ binding in laminae III and V of the frontal, parietal, temporal, occipital, anterogenual cortexes, and entorhinal area. $5-\mathrm{HT}_{2 \mathrm{~A}} \mathrm{Rs}$ are also visualized in the mammillary bodies of the hypothalamus, claustrum, and the lateral nucleus of the amygdala. The hippocampus, caudate, putamen, and accumbens nuclei present an intermediate density of binding. Areas such as the thalamus, brain stem, cerebellum and spinal cord contained only low to very low densities of binding (Pazos et al., 1987). In situ hybridization studies reveal that $5-\mathrm{HT}_{2 \mathrm{~A}} \mathrm{R}$ mRNA is present in all neocortical areas, especially in layer 5 pyramidal neurons, and in putative interneurons. $5-\mathrm{HT}_{2 \mathrm{~A}} \mathrm{R}$ mRNA was observed at minimal levels in the hippocampus and not in the raphe, cerebellum, substantia nigra or striatum (Burnet et al., 1995).

Morphological and double immunofluorescence analyses confirmed the presence of $5-\mathrm{HT}_{2 \mathrm{~A}} \mathrm{Rs}$ on pyramidal neurons, interneurons, and glial cells in neocortex, amygdala and hippocampus (Willins et al., 1997; Bombardi, 2012, 2014). Thus, predicting the functional influence of activated cortical $5-\mathrm{HT}_{2 \mathrm{~A}} \mathrm{Rs}$ is not straightforward, since these receptors would be capable of direct excitation and modulating feed-forward inhibition. In addition, 5- $\mathrm{HT}_{2 \mathrm{~A}} \mathrm{Rs}$ are located on cholinergic (Quirion et al., 1985) and glutamatergic neurons (Hasuo et al., 2002). $5-\mathrm{HT}_{2 \mathrm{~A}} \mathrm{R}$ immunolabeling was also observed on glial cells in many forebrain regions: astrocytes were identified by double immunolabeling as cells in which $5-\mathrm{HT}_{2 \mathrm{~A}} \mathrm{R}$ and GFAP was colocalized (Xu and Pandey, 2000); and on microglia (Glebov et al., 2015). These findings demonstrate that consideration of the serotonin-mediated signaling at $5-\mathrm{HT}_{2 \mathrm{~A}} \mathrm{Rs}$ must include pathways that involve neurons and glial cells alike. It will be of interest to determine the degree to which functional influences expressed by the activation of $5-\mathrm{HT}_{2 \mathrm{~A}} \mathrm{Rs}$ are dependent upon neurons, astrocytes, and microglial cells, and to determine whether clinically relevant features of $5-\mathrm{HT}_{2 \mathrm{~A}} \mathrm{Rs}$ are related to changes in neurons or astrocytes.

At the subcellular level, 5- $\mathrm{HT}_{2 \mathrm{~A}} \mathrm{R}$ immunolabeling is found on cell bodies and processes of neurons (Cornea-Hebert et al., 1999; Xu and Pandey, 2000); in particular, at both pre- and post-synaptic compartments (Miner et al., 2003). However, the majority of evidence suggests a predominant expression at postsynaptic dendritic spines and shafts of non-5-HT neurons. Our own immuno-electron microscopy data revealed that 5$\mathrm{HT}_{2 \mathrm{~A}} \mathrm{R}$ is also distributed in the dendritic spines, shafts, and presynaptic terminals of CA1 neurons in the mouse dorsal hippocampus (Zhang et al., 2015). Consideration should also be given to evidence suggesting that $5-\mathrm{HT}_{2 \mathrm{~A}} \mathrm{R}$ subunits are extensively and dynamically trafficked between the cytoplasm and the neuronal membrane, as much $5-\mathrm{HT}_{2 \mathrm{~A}} \mathrm{R}$ label has been identified at cytoplasmic rather than membrane bound compartments in adult rat neocortex (Cornea-Hebert et al., 1999). It will be of interest to determine the corresponding function of $5-\mathrm{HT}_{2 \mathrm{~A}} \mathrm{R}$ subunit trafficking between the respective neuronal sub-compartments, and the intracellular signaling that promotes trafficking.

\section{Interacting Proteins}

Multiple interacting proteins regulate the function of $5-\mathrm{HT}_{2 \mathrm{~A}} \mathrm{Rs}$ in the membrane. $5-\mathrm{HT}_{2 \mathrm{~A}} \mathrm{Rs}$ interact with multiple $\mathrm{PDZ}$ protein1 (MUPP1) and PSD-95 PDZ proteins (Jones et al., 2009). The $5-\mathrm{HT}_{2 \mathrm{~A}} \mathrm{R}$ colocalizes with PSD-95 and with MUPP1 in a subset of dendritic spines of rat cortical pyramidal neurons. $\mathrm{PDZ}$ proteins are vital for docking $5-\mathrm{HT}_{2 \mathrm{~A}} \mathrm{R}$ to the dendrites in cortical neurons and preventing the internalization of $5-\mathrm{HT}_{2 \mathrm{~A}} \mathrm{Rs}$ (Xia et al., 2003). MUPP1 is enriched in dendritic spine PSD domains of pyramidal neurons and enhances the localization of $5-\mathrm{HT}_{2 \mathrm{~A}} \mathrm{R}$ to the cell surface. Within cortical pyramidal neurons, PSD-95 regulates the functional activity of $5-\mathrm{HT}_{2 \mathrm{~A}} \mathrm{R}$ by promoting apical dendritic targeting and stabilizing receptor turnover. The complex of $5-\mathrm{HT}_{2 \mathrm{~A}} \mathrm{R}$ and PSD-95 plays a key 
role in $5-\mathrm{HT}_{2 \mathrm{~A}} \mathrm{R}$-mediated head-twitch behavior in mice (Abbas et al., 2009). Binding of calmodulin to the $5-\mathrm{HT}_{2 \mathrm{~A}} \mathrm{R} \mathrm{C}$-terminus impedes PKC-mediated phosphorylation of the $5-\mathrm{HT}_{2 \mathrm{~A}} \mathrm{R}$, thus, preventing its desensitization (Turner and Raymond, 2005). Conversely, association of p90-RSK2 with 5- $\mathrm{HT}_{2 \mathrm{~A}} \mathrm{R}$ (intracellular 3 loop) silences the GPCR's signaling (Sheffler et al., 2006). Caveolin-1 interacts with $5-\mathrm{HT}_{2 \mathrm{~A}} \mathrm{R}$ and profoundly modulates its signaling by facilitating the interaction of $5-\mathrm{HT}_{2 \mathrm{~A}} \mathrm{R}$ with $\mathrm{G} \alpha \mathrm{q}$ (Bhatnagar et al., 2004). 5- $\mathrm{HT}_{2 \mathrm{~A}} \mathrm{R}$ and the light chain 2 domain of the microtubule-associated protein MAP1A are co-localized in the intracellular compartment of pyramidal neuronal dendrites of adult rats and may participate in intraneuronal signaling processes involving cytoskeletal elements (Cornea-Hebert et al., 2002). In consideration of these properties, we suggest that altering $5-\mathrm{HT}_{2 \mathrm{~A}} \mathrm{R}$-coupled proteins and pathways may enable an alternative method to selectively promote distinct modulatory functions of $5-\mathrm{HT}_{2 \mathrm{~A}} \mathrm{Rs}$.

\section{Signaling}

Activation of neuronal $5-\mathrm{HT}_{2 \mathrm{~A}} \mathrm{Rs}$ can induce pleiotropic effects via $G$ protein-dependent, ligand-dependent, and ligandindependent signaling pathways, including phospholipase signaling, ERK pathway, and tyrosine kinase pathway in neurons (Millan et al., 2008; Masson et al., 2012). In most circumstances, activation of $5-\mathrm{HT}_{2 \mathrm{~A}} \mathrm{Rs}$ increases intracellular $\mathrm{Ca}^{2+}$ levels via $\mathrm{G}_{\alpha \mathrm{q}}$-PLC-IP3 signaling (Hagberg et al., 1998). In PFC, activation of $5-\mathrm{HT}_{2 \mathrm{~A}}$ Rs suppresses membrane $\mathrm{Ca}_{\mathrm{v}} 1.2 \mathrm{~L}$-type $\mathrm{Ca}^{2+}$ currents via a $\mathrm{G}_{\alpha \mathrm{q}}$-mediated $\mathrm{PLC} \beta / \mathrm{IP}_{3} /$ calcineurin signaling pathway (Day et al., 2002). 5- $\mathrm{HT}_{2 \mathrm{~A}} \mathrm{R}$ activation also stimulates the

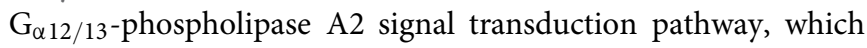
promotes arachidonic acid release (Kurrasch-Orbaugh et al., 2003a,b).

Besides PLC-mediated $\mathrm{Ca}^{2+}$ signaling, $5-\mathrm{HT}_{2 \mathrm{~A}} \mathrm{R}$ activation also induces ERK phosphorylation via diverse intracellular signaling mechanisms (Gooz et al., 2006). Src and calmodulin promote 5-HT2AR-mediated phosphorylation of ERK. In the PC12 cell model system, ERK phosphorylation by $5-\mathrm{HT}_{2 \mathrm{~A}} \mathrm{R}$ may not depend on PLC/PKC signaling, and instead requires an increase in intracellular $\mathrm{Ca}^{2+}$, and the activation of $\mathrm{CaM}$ and Src (Quinn et al., 2002). The ERK target RSK2 directly acts on the third intracellular (i3) loop of $5-\mathrm{HT}_{2 \mathrm{~A}} \mathrm{R}$ protein (Sheffler et al., 2006), leading to direct phosphorylation of the i3 loop at the conserved residue Ser-314 to suppress $5-\mathrm{HT}_{2 \mathrm{~A}} \mathrm{R}$ signaling. In addition, RSK2 is required for tyrosine kinases, such as the epidermal growth factor receptor and the platelet-derived growth factor receptor, both of which have been demonstrated to attenuate $5-\mathrm{HT}_{2 \mathrm{~A}} \mathrm{R}$ functioning in primary cortical neurons (Strachan et al., 2009, 2010).

Besides the $\mathrm{G}$ protein, $5-\mathrm{HT}_{2 \mathrm{~A}} \mathrm{Rs}$ are also coupled to $\beta$-arrestin2. $5-\mathrm{HT}$ binds $5-\mathrm{HT}_{2 \mathrm{~A}} \mathrm{R}$ to stimulate $\mathrm{Akt}$ phosphorylation via the $\beta$-arrestin2/phosphoinositide 3kinase/Src/Akt cascade (Schmid and Bohn, 2010). Application of the $5-\mathrm{HT}_{2 \mathrm{~A}} \mathrm{R}$ agonist DOI to cultured cortical neurons induced phosphorylation of $\mathrm{p} 21$-activated kinase (PAK) via Rac guanine nucleotide exchange factor (RacGEF) kalirin-7 (Jones et al., 2009). The 5- $\mathrm{HT}_{2 \mathrm{~A}} \mathrm{R}$ also regulates the tyrosine kinase pathway activity (Quinn et al., 2002). Excitation of neuronal $5-\mathrm{HT}_{2 \mathrm{~A}} \mathrm{Rs}$ activates transglutaminase which leads to transamidation of Rac1, a small G protein, resulting in constitutive activation of Rac1 (Dai et al., 2008). Chronic treatment with olanzapine, an atypical antipsychotic drug, causes the desensitization of $5-\mathrm{HT}_{2 \mathrm{~A}} \mathrm{R}$ signaling. In rat frontal cortex, stimulation of the JAK-STAT pathway desensitizes the $5-\mathrm{HT}_{2 \mathrm{~A}} \mathrm{R}$-mediated PLC activation induced by olanzapine (Singh et al., 2010). Furthermore, constitutive activation of $5-\mathrm{HT}_{2 \mathrm{~A}}$ Rs induces $\mathrm{G}_{\mathrm{q} / 11}$ phosphorylation and desensitization (uncoupling) (Shi et al., 2007).

As indicated above, $5-\mathrm{HT}_{2 \mathrm{~A}} \mathrm{Rs}$ are also expressed in microglia and mediate 5-HT-induced exosome release (Glebov et al., 2015). Activation of $5-\mathrm{HT}_{2 \mathrm{~A}} \mathrm{R}$ increases intracellular $\mathrm{Ca}^{2+}$ via PLC signaling in astrocytes (Hagberg et al., 1998) and Glu efflux from C6 glioma cells (Meller et al., 2002). Considering the diversity of signaling cascades that can be triggered by $5-\mathrm{HT}_{2 \mathrm{~A}} \mathrm{R}$ activation, it is perhaps not surprising that serotonergic activation of 5$\mathrm{HT}_{2 \mathrm{~A}} \mathrm{Rs}$ can have diverse influences on neuronal responses and CNS functions.

\section{Oligomerization}

The GPCRs can form homomers and heteromers, and thereby present distinct signaling and functional activities (Rios et al., 2001). Consistent with this, $5-\mathrm{HT}_{2 \mathrm{~A}}$ Rs have been shown to form oligomers (Lukasiewicz et al., 2010). Fluorescence resonance energy transfer and immunoprecipitation studies revealed that the human 5- $\mathrm{HT}_{2 \mathrm{~A}} \mathrm{R}$ homodimerizes in cultured cells (Brea et al., 2009). For $5-\mathrm{HT}_{2 \mathrm{~A}} \mathrm{R}$ oligomers, the $5-\mathrm{HT}_{2 \mathrm{~A}} \mathrm{R}$ agonist DOI caused an increase in energy transfer efficiency to the level of $12 \%$, and ketanserin caused a decrease of $4.4 \%$. Heterodimers of $5-\mathrm{HT}_{2 \mathrm{~A}} \mathrm{R}$ and dopamine $\mathrm{D}_{2}$ receptors respond to DOI and quinpirole, a DA $\mathrm{D}_{2} \mathrm{R}$ agonist, with a decrease in FRET efficiency, while ketanserin and butaclamol increase the transfer efficiency value (Lukasiewicz et al., 2010). Heterodimers of 5$\mathrm{HT}_{2 \mathrm{~A}} \mathrm{R}$ and mGluR2 receptor form via the linking domain in transmembrane- 4 and -5 segments, and are present in the human brain. Post-mortem studies indicate a reduced density of these functional complexes in brains of schizophrenics (GonzalezMaeso et al., 2008). Delta-9-tetrahydrocannabinol (THC), the main psychoactive compound of marijuana, induces memory impairments, anxiety, dependence, and analgesia. Vinals et al. (2015) recently reported that amnesic and anxiolytic effects, but not analgesia, induced by THC were suppressed in $5-\mathrm{HT}_{2 \mathrm{~A}} \mathrm{R}$ knockout mice. Molecular studies revealed that cannabinoid CB1 receptors $(\mathrm{CB} 1 \mathrm{R})$ and the $5-\mathrm{HT}_{2 \mathrm{~A}} \mathrm{R}$ physically interact with each other to form heteromers, which are distributed extensively in hippocampus, cortex, and dorsal striatum, but not in the NAc. In vivo experiments have revealed that stimulation of $\mathrm{CB} 1 \mathrm{R}$ and $5-\mathrm{HT}_{2 \mathrm{~A}} \mathrm{R}$ reduces cell signaling, and the binding of an antagonist to one receptor blocks signaling of the interacting receptor. Heteromer formation leads to a switch in $5-\mathrm{HT}_{2 \mathrm{~A}} \mathrm{R}$ mediated G-protein coupling from $G_{\alpha q}$ to $G_{i}$. Synthetic peptides with the sequence of transmembrane helices 5 and 6 of CB1R disrupt $\mathrm{CB} 1 \mathrm{R}$ and $5-\mathrm{HT}_{2 \mathrm{~A}} \mathrm{R}$ heteromerization in vivo, leading to a selective abrogation of memory impairments, but not the antinociceptive properties caused by THC exposure (Vinals et al., 2015). The anatomy, biology and function of $5-\mathrm{HT}_{2 \mathrm{~A}} \mathrm{R}$ 
homomers and heteromers, including the dynamic formation and dissociation, distribution, signaling and function, remain elusive. Elucidation of 5- $\mathrm{HT}_{2 \mathrm{~A}} \mathrm{R}$ oligomers will be interesting for both basic science research and potential clinical applications.

\section{Allosteric Modulation}

Recent years have witnessed a tremendous advance in the research and development of novel compounds for GPCRs that bind allosteric sites to regulate receptor structure and function. These ligands provide high specificity, novel modes of efficacy and may open up a novel avenue for therapeutic agents against multiple mental and neurological disorders. Allosteric modulators bind to a site distinct from that of the orthosteric ligand-binding site. Usually the allosteric modulator induces a structure change within the GPCR to enhance or suppress the orthosteric ligand's functional activity (Conn et al., 2009; Melancon et al., 2012). Application of the amidated lipid, oleamide significantly potentiated 5-HT-induced hydrolysis of phosphoinositide in pituitary P11 cells expressing endogenously $5-\mathrm{HT}_{2 \mathrm{~A}}$ Rs (Thomas et al., 1997). Taken together, these results indicate that there are several binding sites present on $5-\mathrm{HT}_{2 \mathrm{~A}} \mathrm{Rs}$, and we suggest that it will be of interest to further characterize the functional significance of the distinct ligand-driven actions at the $5-\mathrm{HT}_{2 \mathrm{~A}} \mathrm{R}$.

\section{Constitutive Activity}

As mentioned above, $5-\mathrm{HT}_{2 \mathrm{~A}}$ Rs can also be constitutively active (i.e., via activating the receptor in an agonist-independent activity) in vivo (Berg et al., 2008). The inverse 5- $\mathrm{HT}_{2 \mathrm{~A}} \mathrm{R}$ agonists (e.g., risperidone and ketanserin) produce a great suppression of basal IP production, leading to a reduction of basal activity in the $\mathrm{C} 322 \mathrm{~K}$ mutant $5-\mathrm{HT}_{2 \mathrm{~A}} \mathrm{R}$ (Egan et al,, 1998). The "constitutively active" arrestin mutant (Arr2-R169E) induces agonist-independent $5-\mathrm{HT}_{2 \mathrm{~A}} \mathrm{R}$ internalization, and a constitutive translocation of the Arr2-R169E mutant to the plasma membrane (Gray et al., 2003). The constitutive activity of $5-\mathrm{HT}_{2 \mathrm{~A}} \mathrm{Rs}$ may represent another mechanism of regulating cellular function. The specific relationships of these constitutively active $5-\mathrm{HT}_{2 \mathrm{~A}} \mathrm{R}$-mediated properties to distinct behaviors have not been determined.

\section{Electrophysiological Characteristics}

Electrophysiological studies reveal complex effects of $5-\mathrm{HT}_{2 \mathrm{~A}} \mathrm{R}$ activation on cortical neurons; however, mainly these receptors appear to mediate depolarizing effects on excitatory and inhibitory neurons. Slice recordings from prefrontal cortical neurons indicate depolarizing effects following $5-\mathrm{HT}_{2 \mathrm{~A}} \mathrm{R}$ activation (Aghajanian and Marek, 1999; Zhou and Hablitz, 1999; Avesar and Gulledge, 2012). Local application of DOI, a $5-\mathrm{HT}_{2 \mathrm{~A} / 2 \mathrm{C}}$ receptor agonist, increases the firing rates of cortical neurons (Stein et al., 2000) and facilitates synaptic plasticity through an NMDAR-dependent mechanism in presumptive pyramidal neurons of the rat BLA (Chen et al., 2003). Meanwhile, $\alpha$-methyl-5-hydroxytryptamine (a $5-\mathrm{HT}_{2} \mathrm{R}$ agonist) and DOI induce activation of GABAergic interneurons of the rat BLA (Stein et al., 2000). Double immunofluorescence labeling demonstrated that the $5-\mathrm{HT}_{2 \mathrm{~A}} \mathrm{R}$ is primarily localized to parvalbumin-containing BLA interneurons. Accordingly, 5-HT primarily acts on $5-\mathrm{HT}_{2 \mathrm{~A}} \mathrm{Rs}$ to potentiate GABAergic inhibition. 5- $\mathrm{HT}_{2 \mathrm{~A}} \mathrm{R}$ activation increases the frequency and amplitude of sIPSCs recorded from the pyramidal neurons in BLA of the juvenile rat (Jiang et al., 2009). DOI potentiates NMDAR-mediated changes in membrane potentials and calcium influx without affecting the neuronal resting membrane potential or input resistance. However, DOI does not affect AMPA/kainate receptor-mediated excitatory synaptic responses (Chen et al., 2003). The relationship of 5- $\mathrm{HT}_{2 \mathrm{~A}}$ Rs to NMDARs is consistent with the view that $5-\mathrm{HT}_{2 \mathrm{~A}} \mathrm{Rs}$ may be an effective target for modulating experience-dependent synaptic plasticity in the CNS. Globally, $5-\mathrm{HT}_{2 \mathrm{~A}} \mathrm{Rs}$ have been shown to influence low-frequency field potential oscillations in rat frontal cortex (Celada et al., 2008). Taken together, these findings demonstrate that the 5- $\mathrm{HT}_{2 \mathrm{~A}} \mathrm{R}$ mediates 5-HT-induced excitation of cortical neurons. However, much remains to be determined as to the neurophysiological consequences of $5-\mathrm{HT}_{2 \mathrm{~A}} \mathrm{R}$ activation, in particular as they relate to the regulation of specific behaviors.

Recent molecular and pharmacological research has made significant advances in the understanding of the functional selectivity of 5-HT $2 \mathrm{~A}$ R. The multiple signaling pathways suggests bias agonism and bias signaling of $5-\mathrm{HT}_{2 \mathrm{~A}} \mathrm{Rs}$, which posit that an agonist can produce a mix of signaling, which is potentially determined by cell type and functional status.

\section{5-HT $2 \mathrm{~A}$ R Functions in CNS}

Long-term declarative or episodic memory is supported by a network of brain structures in the medial temporal lobe of the mammalian brain. The medial temporal lobe memory system, which includes the hippocampus, dentate gyrus, and surrounding extrahippocampal cortical regions, influence decision-making processes guided by the PFC, and posterior parietal cortex (Squire et al., 2004, 2007; Preston and Eichenbaum, 2013). Serotonergic fibers originating from the raphe nuclei innervate many of the critical nodes within the medial temporal lobe memory system, including the hippocampus and amygdala, and on to the PFC (Vertes, 1991; Vertes et al., 1999). The modulatory influence of 5-HT on simple and more complex forms of learning and memory has been extensively examined in both invertebrate and vertebrate model systems (Kandel and Squire, 2000). The relevance of 5-HT to memory seems to generalize across mammals:, dietary tryptophan increases brain 5-HT levels and improves memory in rodents (Khaliq et al., 2006), the elderly, AD patients, and schizophrenics (Levkovitz et al., 2003; Porter et al., 2003). Further, reductions in brain 5HT concentrations after acute or chronic tryptophan depletion has been demonstrated to impair contextual fear memory in mice (Uchida et al., 2007), object memory in rats (Jenkins et al., 2009), and declarative memory in humans (Schmitt et al., 2006). Below, we describe some evidence suggesting that the $5-\mathrm{HT}_{2 \mathrm{~A}} \mathrm{R}$ may hold special significance as one of the substrates by which 5-HT regulates learning and memory (Meneses, 2007). 


\section{Learning and Memory}

Polymorphisms in the human HTR2A gene are associated with altered memory processes. For example, a HTR $2 A$ gene polymorphism inducing the substitution of the His 452 on the receptor subunit to a Tyr residue is associated with a significant impairment in memory recall amongst adults (de Quervain et al., 2003; Sigmund et al., 2008; Zhu et al., 2013). Carriers of the His452Tyr (rs6314) exhibited poor verbal delayed recall and recognition, but performed equivalent to controls on tests of immediate recall, attentional, and executive function (Wagner et al., 2008). Compared to His homozygotes, Tyr carriers exhibited a diminished hippocampal response to novel stimuli and a higher tendency to judge novel stimuli as familiar during delayed recognition (Schott et al., 2011). Amongst schizophrenics and healthy controls, those carriers of homozygous CC (T102C) and GG (A-1438G), or carriers of the so-called T-allele (rs6314), of the HTR2A gene polymorphisms exhibited significantly impaired short-term verbal memory (Alfimova et al., 2009), and spatial working memory (Blasi et al., 2013). Another polymorphism in the HTR2A gene, referred to as rs4941573 was found to be predictive of increased error rate in a spatial working memory task in an adult Chinese subject population (Gong et al., 2011). These results provide just a brief and incomplete view of a broad literature indicating the impressive degree to which alterations in the HTR2A gene relate to disordered cognitive functions in normal and abnormal human subjects.

The regional distribution of $5-\mathrm{HT}_{2 \mathrm{~A}} \mathrm{Rs}$ can be predictive of the memory capacities that are sensitive to serotonin manipulation. The $5-\mathrm{HT}_{2 \mathrm{~A}} \mathrm{Rs}$ are widely expressed in the neocortex and hippocampus of rats (Xu and Pandey, 2000; Hannon and Hoyer, 2008), rabbits (Aloyo and Harvey, 2000), primates (Jakab and Goldman-Rakic, 1998; Lopez-Gimenez et al., 1998), and humans (Hoyer et al., 1986; Lopez-Gimenez et al., 1998). Table 1 summarizes the major findings of studies in which the learning and memory effects were examined after $5-\mathrm{HT}_{2 \mathrm{~A}} \mathrm{R}$ pharmacological manipulations across distinct tasks and different species. The inconsistency of experimental results may be attributed to the species, selectivity and dose of drug, behavioral task and other effectors.

\section{Object Memory}

The spontaneous NOR task, which relies on rodents' inherent preference for exploring novel over familiar stimuli, has become a popular method for examining the neuropharmacological and neurophysiological mechanisms of object memory (Ennaceur, 2010; Cohen and Stackman, 2015). In the task, rodents are exposed to one or two novel objects in a familiar enclosure during a sample session (i.e., training). The rodent is removed from the enclosure after it has sufficiently explored the objects. After a delay of some length, the rodent is returned to the enclosure for a memory test session, during which the enclosure contains one familiar object and a novel object. If the rodent has successfully encoded and consolidated the memory of the original object from the sample session, then it is expected that the rodent will preferentially explore the novel object during the test session. The NOR task offers advantages for testing rodent memory in that the distinct memory processes of encoding, consolidation and retrieval are operationally defined as events occurring during the sample session, after the sample session, or during the test session, respectively. Another advantage is that the behavioral responses are spontaneous rather than requiring overt motivation such as electrical shock or food restriction. Our recent studies implicate the hippocampus as a key region in the rodent brain for object memory processes (Cohen et al., 2013; Cohen and Stackman, 2015). In light of the fact that 5$\mathrm{HT}_{2 \mathrm{~A}} \mathrm{Rs}$ are densely expressed in the hippocampus (Luttgen et al., 2004), we examined the contribution of hippocampal $5-\mathrm{HT}_{2 \mathrm{~A}} \mathrm{Rs}$ in object memory processes in male mice using an NOR task (see Figure 1). Systemic activation of $5-\mathrm{HT}_{2 \mathrm{~A}} \mathrm{Rs}$ with the selective agonist, TCB-2 after the sample session significantly enhanced the time mice spent exploring the new object presented during the test session $24 \mathrm{~h}$ later (Zhang et al., 2013). The memoryenhancing effect of TCB-2, was blocked by pretreatment with the $5-\mathrm{HT}_{2 \mathrm{~A}} \mathrm{R}$ antagonist, MDL 11,939, which suggests that 5$\mathrm{HT}_{2 \mathrm{~A}} \mathrm{R}$ activation enhances the consolidation of object memory. Interestingly, when TCB-2 was administrated before the sample session, or before the test session, the $5-\mathrm{HT}_{2 \mathrm{~A}} \mathrm{R}$ agonist failed to increase novel object preference relative to the respective control group. Together, these data suggest that $5-\mathrm{HT}_{2 \mathrm{~A}} \mathrm{R}$ activation selectively potentiates memory consolidation. Furthermore, the selective local microinfusion of TCB-2 into the CA1 region of dorsal hippocampus recapitulated the memory enhancing effect observed after systemic treatment (Zhang et al., 2015). The relevance of the $5-\mathrm{HT}_{2 \mathrm{~A}} \mathrm{R}$ for object memory processes was also demonstrated by results of a study showing that the local infusion of the $5-\mathrm{HT}_{2 \mathrm{~A}} \mathrm{R}$ antagonist MDL 11,939 into the mPFC impaired retrieval of object-in-context memory in rats (Bekinschtein et al., 2013). Interestingly, the $5-\mathrm{HT}_{2 \mathrm{~A}} \mathrm{R}$ agonist DOI was found to impair retrieval of memory for an operant response by adult rats in an autoshaping task (Meneses, 2007). Thus, it would appear that the influence of the $5-\mathrm{HT}_{2 \mathrm{~A}} \mathrm{R}$ on memory is taskand memory system-dependent, and perhaps by the underlying neural circuitry that supports the respective memory process.

The encoding and consolidation of hippocampal-dependent memory appears, in part, to require fast glutamatergic neurotransmission, ensuing phases of synaptic plasticity, and dynamic replay of experience-dependent neurophysiological oscillatory activity within hippocampal cell populations (Eichenbaum, 1999; Karlsson and Frank, 2009). Our published (Zhang et al., 2013) data show that post-training activation of $5-\mathrm{HT}_{2 \mathrm{~A}} \mathrm{R} \mathrm{s}$ enhances object memory, likely by affecting consolidation. Prevailing views state that the hippocampus transfers recent to-be-remembered information to the neocortex during sharp wave ripples of the hippocampal local field potential (i.e., 100-200 Hz ripples; Chrobak and Buzsaki, 1996; Carr et al., 2011). During sleep, hippocampal neurons 'replay' patterns of spike trains present during a learning episode. As sharp wave ripples and replay may represent systems consolidation of memory, it would be of interest to examine the influence of $5-\mathrm{HT}_{2 \mathrm{~A}} \mathrm{R}$-sensitive drugs on sharp wave ripples and replay of spiking sequences during sleep episodes after a to-be-remembered experience. Postsynaptic $5-\mathrm{HT}_{2 \mathrm{~A}} \mathrm{Rs}$ may modulate object memory consolidation by also influencing NMDAR-mediated synaptic plasticity. Consistent 
TABLE 1 | Reported effects on learning and memory after pharmacological manipulation of $5-\mathrm{HT}_{2 A}$ receptors $\left(5-\mathrm{HT}_{2 A} R \mathbf{R}\right)$.

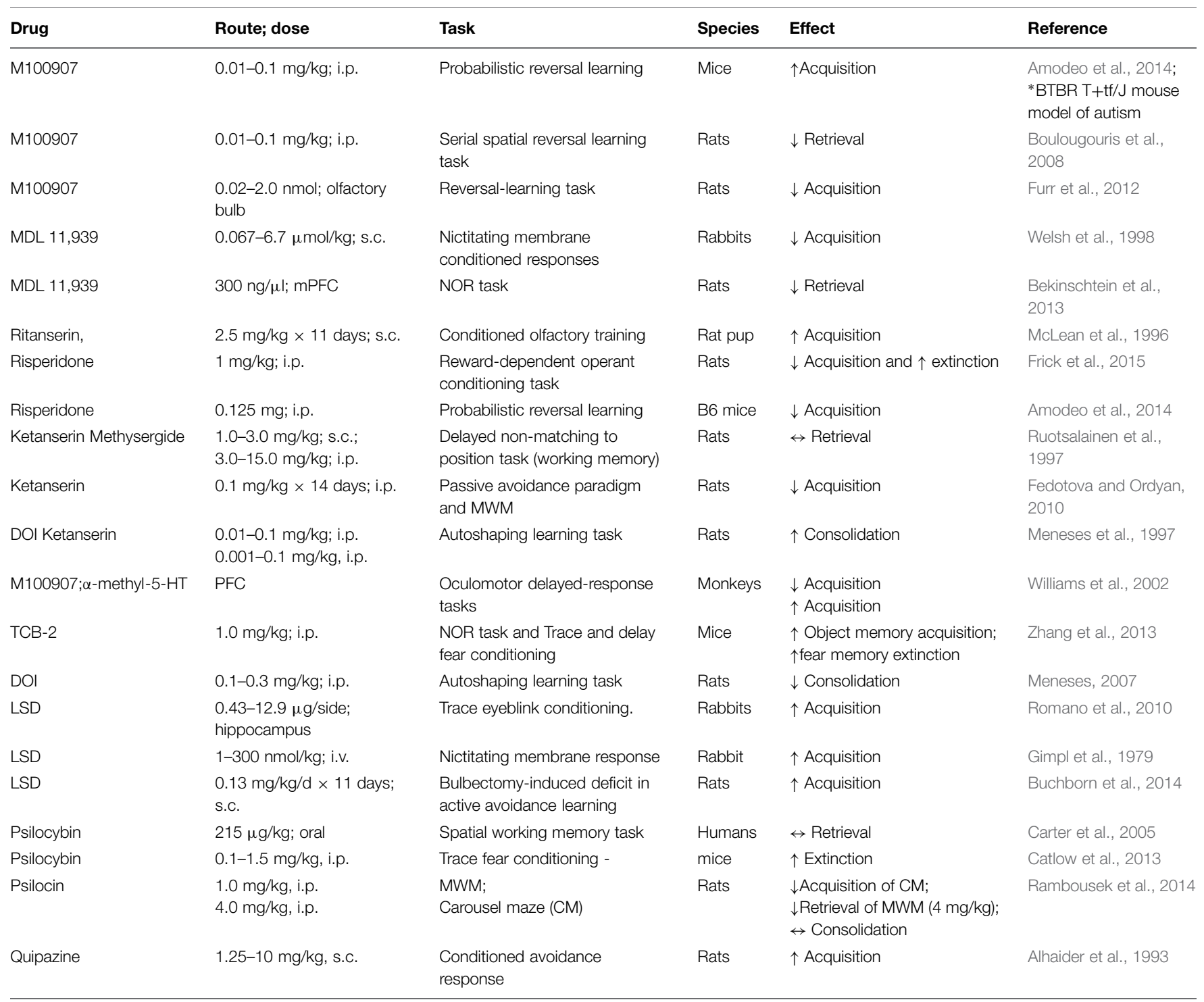

$\uparrow$, enhance; $\downarrow$, suppress; $\leftrightarrow$, no effect.

with this possibility, hippocampal $5-\mathrm{HT}_{2 \mathrm{~A}} \mathrm{Rs}$ are predominantly expressed at dendritic sites on pyramidal neurons (CorneaHebert et al., 1999; Peddie et al., 2008). 5- $\mathrm{HT}_{2 \mathrm{~A}} \mathrm{R}$-containing dendritic processes also were immunolabeled for the NMDAR subunit NR1 and GluR2 (Peddie et al., 2008). We have found that $5-\mathrm{HT}_{2 \mathrm{~A}} \mathrm{R}$ activation increased the extracellular efflux of glutamate in the dorsal hippocampus, and increased the basal firing rates of CA1 pyramidal neurons in awake behaving mice (Zhang et al., 2015). These results suggest that the $5-\mathrm{HT}_{2 \mathrm{~A}} \mathrm{R}$ activation induced facilitation of object memory consolidation, may result from the potentiation of hippocampal glutamate release, and pyramidal neuron temporal dynamics at a critical post-training time period. These data suggest that the $5 \mathrm{HT}_{2 \mathrm{~A}} \mathrm{R}$ may serve as a drug target for pharmacological interventions to treat memory impairments. It is conceivable that $5-\mathrm{HT}_{2 \mathrm{~A}} \mathrm{R}$ activation promotes an increase in intracellular $\mathrm{Ca}^{2+}$, combined with NMDAR-mediated $\mathrm{Ca}^{2+}$ influx, which together would facilitate the behavior-initiated synaptic plasticity. Aghajanian and Marek (1999) reported that activation of $5-\mathrm{HT}_{2 \mathrm{~A}} \mathrm{R}$ produces an elevation in the frequency and amplitude of neuronal sEPSP/sEPSC. Consistently, 5- $\mathrm{HT}_{2 \mathrm{~A}} \mathrm{R}$ activation has been shown to facilitate NMDAR activity and synaptic plasticity in the cortex (Arvanov et al., 1999) and BLA (Chen et al., 2003). Furthermore, $5-\mathrm{HT}_{2 \mathrm{~A}} \mathrm{R}$ directly interacts with PSD-95 to regulate receptor trafficking and signaling (Xia et al., 2003). 5- $\mathrm{HT}_{2 \mathrm{~A}} \mathrm{R}$ activation induces a transient increase in dendritic spinogenesis (Yoshida et al., 2011), phosphorylation of PAK, neuronal Rac guanine nucleotide exchange factor (Jones et al., 2009), BDNF expression (Vaidya et al., 1997), and Erk mitogen-activated protein kinase activity (Florian and Watts, 1998; Watts, 1998). Finally, the $5-\mathrm{HT}_{2 \mathrm{~A}} \mathrm{R}$ inverse agonist pimavanserin was shown to reverse NMDAR antagonism-induced object memory impairments in 
A
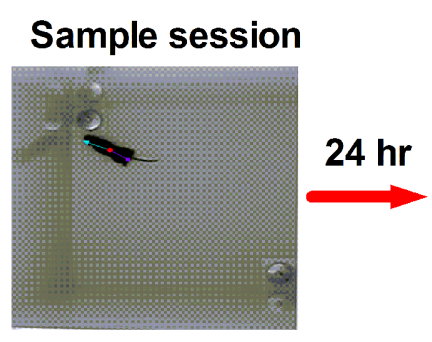

Test session

B

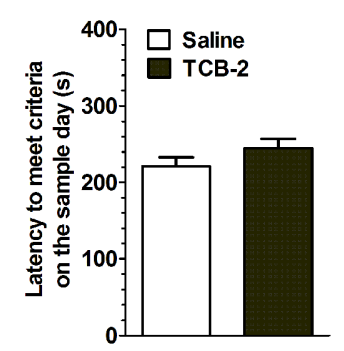

C

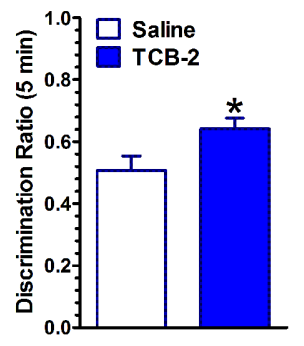

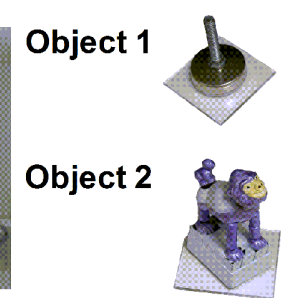

D

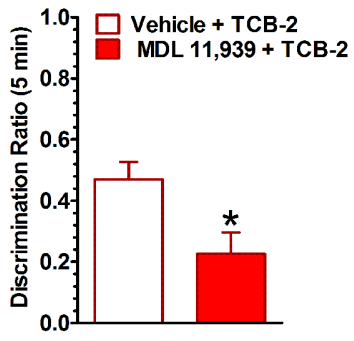

FIGURE 1 | Activation of 5- $\mathbf{H T}_{2 A}$ Rs enhances the consolidation of object memory. (A) Experimental strategy. Left, during the sample session, mice were allowed to explore two identical novel objects each for at least $15 \mathrm{~s}$, or either one for $18 \mathrm{~s}$ within a 10-min sample session. Middle, during the test session $24 \mathrm{~h}$ later, one of the objects (a cabinet leveling foot) was replaced with a novel object (a plastic toy monkey) and mice were individually reintroduced to the arena. Right, the objects used in this study. (B) There was no difference in the latency to achieve exploration criteria during the sample session between the saline- and TCB-2-treated mice. (C) Mice that received TCB-2 right after the sample session exhibited a significantly stronger preference for exploring the novel object during the test session: analysis revealed that TCB-2-treated mice had a higher mean discrimination ratio as compared to that of the saline group. (D) MDL 11,939, a selective 5-HT2A $R$ blocker suppressed TCB-2-induced enhancement in object memory (Zhang et al., 2013). ${ }^{*} p<0.05$, vs. respective control condition.

combination with atypical antipsychotic drugs (Snigdha et al., 2010). These results support the view of a modulatory influence of $5-\mathrm{HT}_{2 \mathrm{~A}} \mathrm{R}$ on NMDAR-dependent memory mechanisms. Considering the myriad potential influences of $5-\mathrm{HT}_{2 \mathrm{~A}} \mathrm{R}$ on medial temporal lobe memory mechanisms, there would appear to be multiple downstream influences by which $5-\mathrm{HT}_{2 \mathrm{~A}} \mathrm{R}$ activation could enhance memory.

\section{Fear Memory}

While there is a rich literature on the influence of serotonin on anxiety and an established contribution of serotonergic drugs to the remediation of anxiety disorders in humans, the present review will focus on the influence of $5-\mathrm{HT}_{2 \mathrm{~A}} \mathrm{Rs}$ on fear memory encoded during Pavlovian conditioning sessions. Pavlovian fear conditioning has become a popular procedure for examining the neurobiological mechanisms of fear memory. As a Pavlovian conditioning procedure, fear conditioning lends itself well to defining processes of encoding, consolidation and retrieval of fear memory. Fear conditioning taxes a well-defined neural circuit within the amygdala, which in turn interacts with the hippocampus, anterior cingulate, or the PFC, depending on the elements of the conditioning session and the stage of memory processing (Zelikowsky et al., 2014). In addition, considerable attention has been given to investigations of the underlying biology of extinction of fear memory. During a delay fear conditioning session, an innocuous stimulus (e.g., a neutral tone or light) becomes a CS when it is repeatedly presented in such a way that it co-terminates with the presentation of a sufficiently aversive US (e.g., foot shock) (Zhang et al., 2013). The unconditioned response to the foot shock US is typically jumping and running, but the conditioned response to the CS is a defensive freezing response, or the cessation of all movement except for respiration. Thus, the freezing behavior provides a reliable post-conditioning measure of fear memory in rodents (Blanchard and Blanchard, 1969). During fear conditioning, the subject learns to associate the tone CS with the foot shock US, and under certain conditions, learns to associate the foot shock with the environment or context where the conditioning session was presented. Acquisition of both the tone-shock and the context-shock associations requires the amygdala; however, the context-shock associations are also dependent upon the hippocampus (Kim and Fanselow, 1992; Phillips and LeDoux, 1992). There has been considerable debate regarding the involvement of the hippocampus in contextual fear memory since there have been reports that hippocampal lesions impair contextual fear memory (Kim and Fanselow, 1992; Phillips and LeDoux, 1992; Anagnostaras et al., 1999; Stiedl et al., 2000), and others reporting that such lesions spare contextual fear memory (Cho et al., 1999; Wiltgen et al., 2006). Consensus seems to be building for the view that if the rodent is permitted sufficient time to acquire a hippocampal-dependent configural representation of the context (the chamber's geometry, olfactory, visual, tactile, and auditory cues) before the US is presented, then the hippocampus is engaged in associating the contextual memory with the foot shock (Rudy et al., 2002, 2004; Matus-Amat et al., 2004; Zelikowsky et al., 2014). In a trace fear conditioning 
A
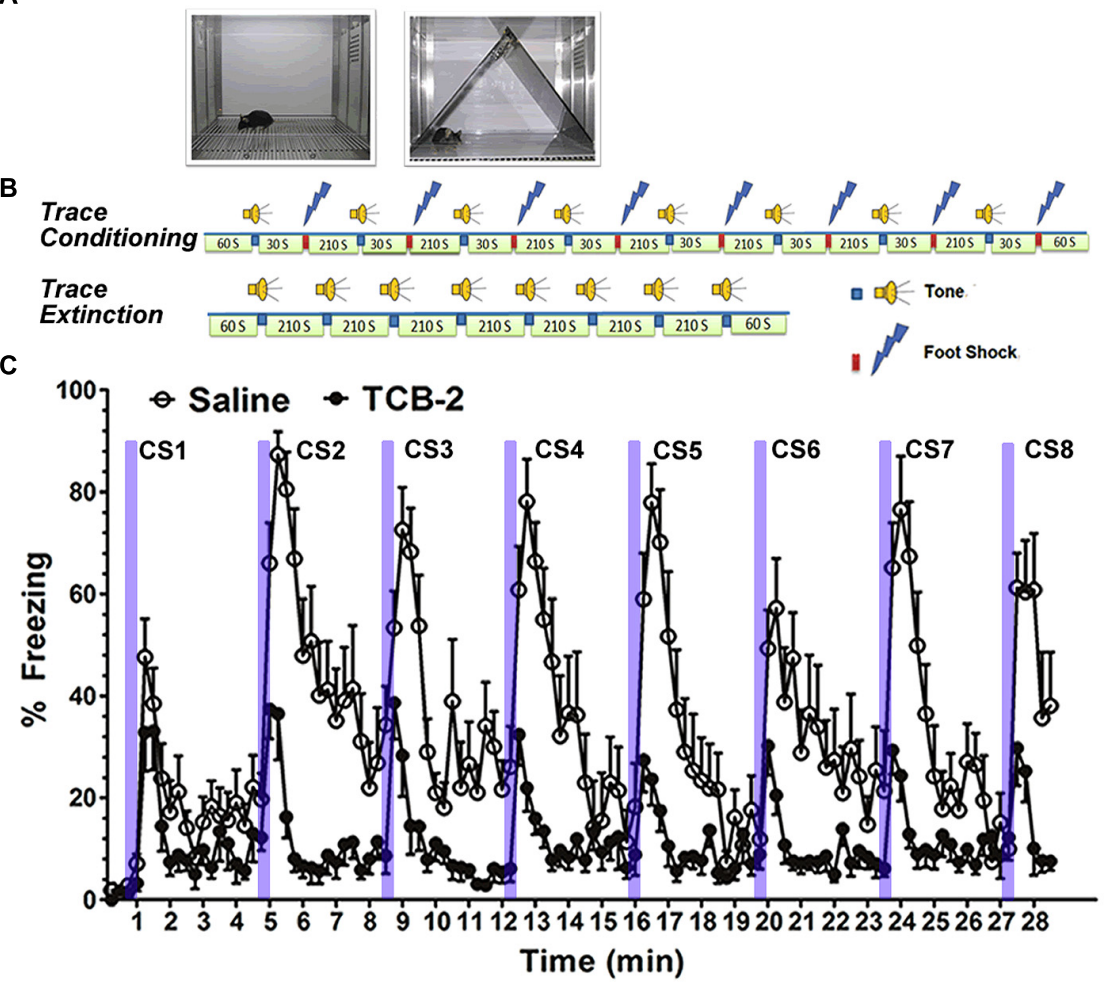

FIGURE 2 | Stimulation of 5- $\mathbf{H T}_{2 \mathbf{A}} \mathbf{R s}$ enhances the acquisition of extinction of trace fear memory. (A) Left, a chamber for fear conditioning (Context A) and contextual fear memory test; right, Context B, a modified chamber with different color, context, light density, and odor for cued fear memory test. (B) Trace fear conditioning training procedure. After a 60-s habitation to Context A, a tone was presented for $15 \mathrm{~s}$ followed by $30 \mathrm{~s}$ stimulus-free interval, and then a 0.5 -s, $0.75 \mathrm{~mA}$ foot shock (US) was presented. The CS-US pairing was repeated eight times with a 210-s intertrial interval (ITI). Mice were removed from the conditioning chamber and returned to their home cages $60 \mathrm{~s}$ after the final CS-US pairing. Trace fear conditioning extinction procedure. Sixty seconds after placing the mouse into the modified chamber, eight unpaired 15-s tone CS were presented with a 120-s ITI. (C) Mice that received TCB-2 (1.0 mg/kg, i.p.) before a trace fear memory extinction test exhibited accelerated acquisition of extinction as indicated by significantly lower freezing scores earlier in the course of extinction as compared to those of vehicle-treated mice. TCB-2 significantly decreased percent freezing from the second to eighth CS presentation (Zhang et al., 2013).

procedure, a temporal gap is imposed between the offset of the tone CS and the onset of the foot shock US. The acquisition of an appropriately timed (i.e., anticipatory) conditioned freezing response occurs progressively over the course of the repeated CS-US pairings; this temporal fear memory is a form of declarative memory dependent on intact hippocampal function in rodents and humans (Clark and Squire, 1998; McEchron et al., 1998; Chowdhury et al., 2005). It should be clear that in deciphering an influence of $5-\mathrm{HT}_{2 \mathrm{~A}} \mathrm{R}$-sensitive drugs on the distinct processes of memory for contextual and/or cued fear, one must consider the specifics of the conditioning protocol used.

Finally, considerable attention has been directed toward defining the mechanisms of fear memory extinction, in part because of extinction's potential relationship to components of the human disorder post-traumatic stress disorder (Jovanovic and Ressler, 2010). Repeated presentations of the CS alone to the fear-conditioned rodent, promotes the acquisition of a new inhibitory association, which dampens or completely suppresses the expression of conditioned fear responses. Distinct subregions of the rodent PFC contribute differentially to fear extinction; that is, the prelimbic cortex appears to influence the expression of fear responses, while the infralimbic cortex influences the acquisition of extinction of fear memory (Quirk et al., 2010; Sierra-Mercado et al., 2011). Synaptic plasticity within mPFCBLA neuronal circuits is induced during fear extinction training, resulting in increased inhibition of CS-elicited activity of BLA extinction neurons (Herry et al., 2008, 2010). Thus, converging evidence implicates the infralimbic and prelimbic cortices of the rodent brain and their differential projections to the amygdala sub-regions and to the hippocampus as contributing significantly to the synaptic plasticity that develops during the acquisition of fear extinction (see Tovote et al., 2015 for a recent review).

We found that systemic administration of the $5-\mathrm{HT}_{2 \mathrm{~A}} \mathrm{R}$ agonist TCB-2 (see Figure 2) significantly enhanced the acquisition of fear extinction in mice that had undergone trace fear conditioning or delay fear conditioning (Zhang et al., 2013). Importantly, the $5-\mathrm{HT}_{2 \mathrm{~A}} \mathrm{R}$ agonist did not affect locomotor responses or baseline freezing in the mice. Therefore, the effect of TCB-2 on fear extinction appeared to be specific to facilitating the acquisition of the new inhibitory memory that 
suppressed fear expression. It is of interest to determine the site of action in the rodent brain at which TCB-2 works to facilitate fear extinction. In light of the plastic changes in neural circuitry that occur during the acquisition of fear extinction, it is possible that TCB-2 influences either the infralimbic cortical neurons or the "extinction neurons" of the BLA to facilitate fear extinction. Izumi and colleagues reported that an amygdala-selective reduction of 5-HT content via site-specific 5,7-DHT injection reduced the expression of conditioned fear responses in rats (Izumi et al., 2012). While this finding is difficult to reconcile with our report that $5-\mathrm{HT}_{2 \mathrm{~A}} \mathrm{R}$ activation enhanced fear extinction, it is possible that the 5-HT denervation may have increased postsynaptic expression of $5-\mathrm{HT}_{2 \mathrm{~A}} \mathrm{Rs}$ in the amygdala, which might in turn impair the expression of fear. It is clear that further studies are needed to clarify the neurophysiological influences of 5-HT, and the $5-\mathrm{HT}_{2 \mathrm{~A}} \mathrm{R}$ in particular, on the neural circuitry supporting fear memory encoding, consolidation, retrieval, and extinction.

The influence of the $5-\mathrm{HT}_{2 \mathrm{~A}} \mathrm{R}$ on the extinction and reconsolidation of fear memory may have significant impact on the development of therapeutic approaches for subjects with fear memory invasion, such as phobias and post trauma stress disorder (Quirk et al., 2010). For decades, the pharmacological manipulation of the 5-HT system has been a useful approach to treat emotional and mental disorders, such as depression and anxiety. Recent progress has suggested a promising therapeutic application of hallucinogenic $5-\mathrm{HT}_{2}$ agonists to treat depression and anxiety (Grob et al., 2011). These results suggest that despite the historical stigma associated with 5$\mathrm{HT}_{2 \mathrm{~A}} \mathrm{R}$ activators as potential hallucinogens, such compounds may provide important medical potential for treating affective and cognitive symptoms associated with emotional and mental conditions.

Glutamatergic neurons in the amygdala, cortex and hippocampus are essential for memory extinction and reconsolidation. Local infusion of NMDAR antagonists into the BLA or CA1 region of hippocampus before extinction training suppresses fear memory extinction and reconsolidation (Baker and Azorlosa, 1996; Szapiro et al., 2003). The NMDAR partial agonist $\mathrm{D}$-cycloserine facilitates the extinction of fear memory (Walker et al., 2002; Ledgerwood et al., 2003). Knockout of NMDAR in hippocampal CA1 pyramidal cells exclusively impairs the establishment of conditioning between the CS and the US during a trace fear conditioning task. These results suggest that the CS representation and conditioning are entrained within hippocampus cell ensembles, probably via NMDAR-dependent synaptic plasticity (McHugh et al., 1996; Huerta et al., 2000). Recall that $5-\mathrm{HT}_{2 \mathrm{~A}} \mathrm{Rs}$ are expressed in the dendrites and dendritic spines of dentate gyrus neurons where NMDARs and AMPARs are assumed to be located (Peddie et al., 2008). $5-\mathrm{HT}_{2 \mathrm{~A}} \mathrm{R}$ activation produces an elevation in the frequency and amplitude of cortical neuronal sEPSP/sEPSCs (Aghajanian and Marek, 1999), facilitates NMDAR activity and synaptic plasticity in the cortex (Arvanov et al., 1999) and BLA (Chen et al., 2003). It is worth while to examine the degree to which NMDARs expressed in the infralimbic and prelimbic cortices contribute to the $5 \mathrm{HT}_{2 \mathrm{~A}} \mathrm{R}$-mediated enhancement in fear extinction.
Converging evidence demonstrates that activation of 5$\mathrm{HT}_{2 \mathrm{~A}} \mathrm{Rs}$ via systemic injection, or by local microinfusion, appears to enhance two forms of hippocampal-dependent memory in mice: object memory and conditioned fear memory. Administration of a selective $5-\mathrm{HT}_{2 \mathrm{~A}} \mathrm{R}$ antagonist alone was not found to significantly affect object memory or fear memory (Zhang et al., 2013), suggesting that memory consolidation does not require serotonergic activation of $5-\mathrm{HT}_{2 \mathrm{~A}} \mathrm{Rs}$ and/or the antagonists do not affect the tonic effect the $5-\mathrm{HT}_{2 \mathrm{~A}} \mathrm{R}$. Activation of $5-\mathrm{HT}_{2 \mathrm{~A}}$ Rs with TCB-2 was also found to facilitate fear memory extinction in mice. These results offer promising support for the view that the $5-\mathrm{HT}_{2 \mathrm{~A}} \mathrm{R}$ may be an important new target for consideration in the search for mechanisms by which long-term memory can be enhanced in humans.

\section{Hallucination vs. Spatial Cognition 5- $\mathrm{HT}_{2 \mathrm{~A}} \mathrm{R}$ and Hallucination}

Recent evidence suggests that activation of $5-\mathrm{HT}_{2 \mathrm{~A}} \mathrm{Rs}$ may promote experiencing visual hallucinations by increasing neuronal excitability and altering visual-evoked cortical responses (Kometer et al., 2013). Hallucination is a type of misperception defined as the perception of an object without there being an object to perceive. Hallucinations are a significant characteristic found in a diversity of psychiatric and neurological states. Hallucinations can be triggered by at least three categories of drugs: psychedelics, (i.e., DOI, TCB-2, LSD, and psilocybin) via activation of $5-\mathrm{HT}_{2 \mathrm{~A}} \mathrm{Rs}$, psychostimulants (i.e., cocaine or amphetamine) via activation of dopamine D2 receptors and dissociative anesthetics (i.e., phencyclidine or ketamine) via blockade of glutamate NMDARs. The signaling and behavioral responses to each hallucinogen are distinct from each other. Activation of $5-\mathrm{HT}_{2 \mathrm{~A}} \mathrm{R}$ is critical for the psilocybin (found in magic mushroom)-induced $\alpha$ oscillations, N170 visual-evoked potentials, and visual hallucinations (Kometer et al., 2013).

5-hydroxytryptamine/serotonin is an endogenous neurotransmitter and is not considered hallucinogenic. Interesting, $\mathrm{N}$-methyltryptamines, a metabolite of 5-HT, also presents high affinity for $5-\mathrm{HT}_{2 \mathrm{~A}} \mathrm{R}$ and can induce hallucinations in a manner independent of $\beta$-arrestin2/phosphoinositide 3-kinase/Src/Akt cascade (Schmid and Bohn, 2010). Signaling for hallucinogens is distinct. Lisuride (an antiparkinsonian agent) and LSD both bind cortical $5-\mathrm{HT}_{2 \mathrm{~A}} \mathrm{R}$, and thereby regulate PLC activity. LSD signaling involves pertussis toxin-sensitive heterotrimeric $\mathrm{G}_{\mathrm{i} / \mathrm{o}}$ proteins and Src (Gonzalez-Maeso et al., 2007). Non-hallucinogenic agonists, for example lisuride, only stimulate cortical $\mathrm{Gq}$ in rats, whereas hallucinogens such as psilocybin (found in magic mushrooms), and LSD stimulate both $\mathrm{G}_{\mathrm{q} / 11}$ and $\mathrm{G}_{i}$ (Gonzalez-Maeso et al., 2007). The $\beta$-arrestin pathway is involved in hallucinogen-mediated head shake responses in rodents (Schmid et al., 2008), and 5-HT induces a head shake response in mice via a $\beta$-arrestin-2-dependent signaling. However, the DOI invoked head shake behavior is not dependent upon $\beta$-arrestin-2 signaling. These findings suggest that the $5-\mathrm{HT}_{2 \mathrm{~A}} \mathrm{R}-\beta$-arrestin interaction may be exclusively for endogenous 5-HT action. Further examination of hallucinogenmediated signaling may have major implications in drug development for treating emotional and mental disorders such 
as depression and schizophrenia (Schmid et al., 2008). More research efforts will need to be focused on the hallucinationinducing aspects of $5-\mathrm{HT}_{2 \mathrm{~A}} \mathrm{R}$-sensitive drugs and, relevant to their potential therapeutic potential, it may be important to consider designing novel compounds that yield more of the beneficial effects, without activating those problematic sensory and perceptual effects.

\section{5- $\mathrm{HT}_{2 \mathrm{~A}} \mathrm{R}$-mediated Hallucination and Spatial Cognition}

$5-\mathrm{HT}_{2 \mathrm{~A}}$ receptors may affect spatial cognition. A human population-based study shows that $5-\mathrm{HT}_{2 \mathrm{~A}} \mathrm{R}$ TT genotype of rs6313 is associated with better spatial cognitive performance (Gong et al., 2011). Kant et al. (1998) reported that the 5- $\mathrm{HT}_{2 \mathrm{~A}} \mathrm{R}$ agonist DOI ( 0.1 and $0.25 \mathrm{mg} / \mathrm{kg}, 30 \mathrm{~min}$ pretreatment) slowed rat performance as assessed by swim time on both a well-learned water maze as well as learning of a new maze, but DOI did not alter error rate on either task. Kant concluded that DOI impaired performance by suppressing motor activity on a water maze (Kant et al., 1998), which was in opposition to another report showing that manipulation of $5-\mathrm{HT}_{2 \mathrm{~A}} \mathrm{R}$ did not impair the latency to a visible platform water maze test (Naghdi and Harooni, 2005). The serotonergic hallucinogens may impair the hippocampal-dependent spatial cognition by acting on $5-\mathrm{HT}_{2 \mathrm{~A}} \mathrm{Rs}$ (Naghdi and Harooni, 2005). However, the direct evidence of 5$\mathrm{HT}_{2 \mathrm{~A}} \mathrm{R}$ on visuospatial cognition and the central target has not been determined.

Serotonergic psychedelics may affect the integrity of visual functioning. Visual-directed spatial cognition and navigation are guided by exteroceptive (e.g., landmarks) and interoceptive (e.g., self-motion information) cues, and their integration. The hippocampus is a pivotal brain region receiving and integrating information for spatial memory and navigation in rodents (Broadbent et al., 2004; Eichenbaum, 2004). The MWM is a classic behavioral task for testing hippocampal-dependent visuospatial cognition, including place learning and memory, orientation and decision-making (Morris et al., 1982; Morris, 1984). Further, hippocampal place cells exhibit location-specific firing, and are considered to be fundamental components of network for spatial problem solving in the mammalian brain (for a review see Moser et al., 2008). The hippocampal neural circuit representing current location, directional heading and its integration is influenced by exteroceptive and interoceptive cues, and is considered to guide spatial cognition and navigation.

We recently found that pre-test activation of $5-\mathrm{HT}_{2 \mathrm{~A}} \mathrm{R}$ with TCB-2 significantly delayed the initiation of an accurate search path by well-trained male mice in the hidden platform MWM (Zhang et al., 2015). Importantly, 5- $\mathrm{HT}_{2 \mathrm{~A}} \mathrm{R}$ activation did not affect swim performance or visual cue-triggered approach behavior in the visible platform water maze task. Taken together, our results suggest that the activation of $5-\mathrm{HT}_{2 \mathrm{~A}} \mathrm{R}$ impairs the retrieval of hippocampal spatial memory, but not the accuracy of spatial information retrieval and decision-making. It is conceivable that the delayed initiation of accurate spatial search by TCB-2-treated mice might reflect the possible visual hallucinatory influences of the $5-\mathrm{HT}_{2 \mathrm{~A}} \mathrm{R}$ agonist. For example, perhaps TCB-2-induced a brief aberration of visual input that slowed the perception of current position and local view of the mouse at the start of the water maze probe test. Once, reconciled or reoriented, the mouse was able to swim accurately to the remembered spatial location of the platform. It will be of interest to determine where in the brain TCB-2 is acting to alter spatial memory retrieval. The relatively weak influence of TCB-2-induced visual hallucination on spatial navigation may due to the difference in the visual information passing through the brain and central targets processing the information.

Taken together, the results we have reported here of memory effects after activation of the $5-\mathrm{HT}_{2 \mathrm{~A}} \mathrm{R}$ represent a fairly complex picture. The post-training administration of TCB-2 enhanced consolidation of object memory in mice. Pre-test administration of TCB-2 did not affect retrieval of object memory, yet delayed retrieval of spatial memory. Pre-extinction training administration of TCB-2 facilitated the acquisition of extinction of both trace and delay fear memories. The facilitating effect of TCB-2 on fear extinction may have been the result of a combined effect of suppressing fear expression - possibly a consequence of impaired retrieval of fear memory, and enhancing the encoding and consolidation of fear extinction. To characterize the 5$\mathrm{HT}_{2 \mathrm{~A}} \mathrm{R}$ agonist as a cognitive enhancer based solely on our object memory results, would be to ignore the other experimental findings. We are interested in conducting a more comprehensive analysis of the impact of TCB-2 on multiple forms of memory. For example, it will be interesting to examine whether postconditioning TCB-2 might enhance the consolidation of fear memory, in a manner consistent with that observed in the NOR task. Likewise, it will be interesting to test whether postextinction training TCB-2 facilitates the consolidation of fear extinction. Results of these experiments will help in better appreciating the modulatory influence of the $5-\mathrm{HT}_{2 \mathrm{~A}} \mathrm{R}$ on longterm memory processes. This synthesis of recent findings of the influences of $5-\mathrm{HT}_{2 \mathrm{~A}} \mathrm{R}$ activation should provide a credible argument that the $5-\mathrm{HT}_{2 \mathrm{~A}} \mathrm{R}$ participates significantly to the well-documented contribution of 5-HT to memory (Meneses, 2013).

\section{5- $\mathrm{HT}_{2 \mathrm{~A}} \mathrm{R}$ and Mental Disorders}

A number of psychiatric and neurodegenerative disorders are associated with the variation of structure, expression, and function of $5-\mathrm{HT}_{2 \mathrm{~A}}$ Rs. Positron emission tomography (PET) molecular imaging has the sensitivity to quantify binding of 5$\mathrm{HT}_{2 \mathrm{~A}} \mathrm{Rs}$ in CNS disorders. Medication-free depressed subjects presented greater $5-\mathrm{HT}_{2 \mathrm{~A}} \mathrm{R}$ binding (Bhagwagar et al., 2006). There was a significant reduction in $5-\mathrm{HT}_{2 \mathrm{~A}} \mathrm{R}$ binding in frontal polar, dorsolateral and medial frontal cortex, and parietal and temporal associative cortex of OCD patients and a significant correlation between $5-\mathrm{HT}_{2 \mathrm{~A}} \mathrm{R}$ availability in orbitofrontal and dorsolateral frontal cortex and clinical severity (Perani et al., 2008). Schizophrenia patients present with very high $5 \mathrm{HT}_{2 \mathrm{~A}} \mathrm{R}$ occupancy in the frontal cortex (Talvik-Lotfi et al., 2000). These results suggest that the variation in the number, affinity and/or function of $5-\mathrm{HT}_{2 \mathrm{~A}} \mathrm{R}$ participates in the etiology of mental disorders. 


\section{Alzheimer's Disease}

It is interesting to note that neocortical $5-\mathrm{HT}_{2 \mathrm{~A}} \mathrm{R}$ binding is significantly decreased in patients with early stage $A D$, and in those with mild cognitive impairment; especially in temporal lobe regions associated with long-term memory (Meltzer et al., 1998; Hasselbalch et al., 2008; Santhosh et al., 2009; Marner et al., 2011, 2012). Further, the severity of cognitive impairment in $\mathrm{AD}$ patients correlates with the decrease in $5-\mathrm{HT}_{2 \mathrm{~A}} \mathrm{R}$ binding (Versijpt et al., 2003). Given the pattern of 5- $\mathrm{HT}_{2 \mathrm{~A}} \mathrm{R}$ distribution in neocortical regions and their expression on principal excitatory neurons, it is possible that the marked reduction in $5-\mathrm{HT}_{2 \mathrm{~A}} \mathrm{R}$ in brains of $\mathrm{AD}$ is a direct product of neuron loss in key brain regions. Consistent with evidence from the human studies, the Alzheimer's-like neuropathology and associated memory deficits in rodents, which follow intra-hippocampal injection of B-amyloid(1-42), are associated with a significant reduction in levels of hippocampal $5-\mathrm{HT}_{2 \mathrm{~A}} \mathrm{R}$ expression (Christensen et al., 2008). Although we have focused this analysis on the influence of $5-\mathrm{HT}_{2 \mathrm{~A}} \mathrm{Rs}$ on long-term, hippocampal-dependent memory, there is clear and compelling evidence to suggest that the 5$\mathrm{HT}_{2 \mathrm{~A}} \mathrm{R}$ represents a potential new target by which human longterm memory may be modulated. We assert that it will be of interest in further examine the contribution of $5-\mathrm{HT}_{2 \mathrm{~A}} \mathrm{Rs}$ to memory processes, and we are particularly interested in determining neurophysiological influences of $5-\mathrm{HT}_{2 \mathrm{~A}} \mathrm{R}$ agonists which promote the enhancement of memory consolidation which we have reported in mice.

\section{Drug Memory}

Drug dependence, classified as an impulsive, compulsive, and relapsing psychiatric disorder, represents a devastating societal problem worldwide. The profound symptoms of drug abuse, in particular the cue-elicited relapse to drug use after even long periods of abstinence, are a consequence of robust experiencedependent synaptic plasticity within the brain's reward circuit. Like episodic, semantic, and habit memory, drug-associated memories are persistent and hold a strong influence on current and future behaviors. Of particular interest is the consideration of memory extinction as a psychological tool for remediating the problem of relapse in drug addicts. That is, if the problem of drug abuse is approached as a mental disorder of memory, then pharmacological manipulations that facilitate extinction may hold therapeutic utility for treating drug abuse. Drug exposure alters the expression and function of $5-\mathrm{HT}_{2 \mathrm{~A}} \mathrm{R}$, for example morphine decreases frontocortical 5- $\mathrm{HT}_{2 \mathrm{~A}} \mathrm{R}$ binding affinity in dogs (Adriaens et al., 2012). 5$\mathrm{HT}_{2} \mathrm{Rs}$ are up-regulated in amygdala, midbrain, pons, and medulla of morphine-tolerant and -dependent rats, but not in morphine-abstinent rats (Gulati and Bhargava, 1989). There is considerable evidence that $5-\mathrm{HT}_{2 \mathrm{~A}} \mathrm{Rs}$ modulate the behavioral consequences of repeated exposure to addictive psychomotor stimulants. For example, M100907 suppresses hyperactivity elicited by cocaine (Fletcher et al., 2002), MK801, amphetamine (O'Neill et al., 1999), and morphine (Auclair et al., 2004). DOM, a 5- $\mathrm{HT}_{2 \mathrm{~A}} \mathrm{R}$ agonist, attenuates locomotor-stimulating effects of morphine, which could be prevented by M100907 (Li et al., 2013). Furthermore, M100907 attenuated the ability of experimenter-administered cocaine to reinstate lever pressing (Fletcher et al., 2002) and attenuated the drug associated cue-induced reinstatement of cocaineseeking behavior after extinction (Nic Dhonnchadha et al., 2009). M100907 also suppressed reinstatement induced by nicotine prime or nicotine-associated cue (Fletcher et al., 2012) and sensitization (Zaniewska et al., 2010). Intra-NAc infusions of M 100907 blocked the expression of cocaineinduced locomotor sensitization (Zayara et al., 2011). IntraPFC M100907 decreased cue-elicited reinstatement of cocaine seeking-behavior (Pockros et al., 2011). Together, these results suggest that $5-\mathrm{HT}_{2 \mathrm{~A}} \mathrm{Rs}$ modulate drug addiction-dependent behaviors such as craving and drug-seeking and pharmacological blockade of $5-\mathrm{HT}_{2 \mathrm{~A}} \mathrm{Rs}$ may represent a therapeutic advance in suppression of cue-evoked craving and/or relapse in drug addicts.

\section{Therapeutic Application of $5-\mathrm{HT}_{2 \mathrm{~A}} \mathrm{R}$}

Preclinical and clinical studies have provided support for the use of pharmacological manipulation of $5-\mathrm{HT}_{2 \mathrm{~A}} \mathrm{R}$ to treat the symptoms of mental disorders. Activation of $5-\mathrm{HT}_{2 \mathrm{~A}} \mathrm{R}$ with TCB-2 in the medial septum-diagonal band of Broca complex enhances neuronal activity and working memory in hemiparkinsonian rats ( $\mathrm{Li}$ et al., 2015). M100907 had no effect on attentional performance, but abolished the PCPinduced attentional performance deficits in rats (Poyurovsky et al., 2003). M100907 prevents impairment in attentional performance by NMDAR blockade in the rat PFC (Mirjana et al., 2004). There are a number of $5-\mathrm{HT}_{2 \mathrm{~A}} \mathrm{R}$ drugs that have been evaluated or are being currently evaluated under clinical trials, for example quetiapine ${ }^{1}$ for schizophrenia; M100907 ${ }^{2}$ for depression; ACP- $103^{3}$ for Parkinson's disease; pimavanserin for patients with $\mathrm{AD}$ psychosis ${ }^{4}$ or with Parkinson's disease psychosis ${ }^{5}$.

\section{Conclusion}

In this review, we have summarized recent progress in the signaling, polymerization and allosteric modulation of $5-\mathrm{HT}_{2 \mathrm{~A}} \mathrm{R}$; and have discussed the critical role of $5-\mathrm{HT}_{2 \mathrm{~A}} \mathrm{Rs}$ in a number of cognitive processes. Based on the results of studies from our lab and others, it appears that activation of $5-\mathrm{HT}_{2 \mathrm{~A}} \mathrm{Rs}$ may offer a novel approach to treat the impairment of learning and memory associated with several neurodegenerative disorders. Meanwhile, blockade of $5-\mathrm{HT}_{2 \mathrm{~A}} \mathrm{R}$ may offer a feasible way to suppress drug craving and/or relapse. It will be very interesting to identify the corresponding signaling pathways by which $5-\mathrm{HT}_{2 \mathrm{~A}} \mathrm{Rs}$ modulate these behavioral capacities. Of particular note, we reviewed evidence that $5-\mathrm{HT}_{2 \mathrm{~A}} \mathrm{Rs}$ may dimerize with other receptors, and that certain pathways may promote constitutive activation of

\footnotetext{
${ }^{1}$ https://clinicaltrials.gov/ct2/show/NCT00207064?term=5-HT2A\&rank=2 ${ }^{2}$ https://clinicaltrials.gov/ct2/show/NCT00070694?term =5-HT2A\&rank=5 ${ }^{3} \mathrm{https} / / / \mathrm{clinicaltrials}$.gov/ct2/show/NCT00086294?term=5-HT2A\&rank=12 ${ }^{4}$ https://clinicaltrials.gov/ct2/show/NCT02035553?term=5-HT2A\&rank=41 ${ }^{5} \mathrm{https} / /$ clinicaltrials.gov/ct2/show/NCT00477672?term $=5-\mathrm{HT} 2 \mathrm{~A} \& \mathrm{rank}=46$
} 
5- $\mathrm{HT}_{2 \mathrm{~A}} \mathrm{Rs}$, which likely represent novel receptor signaling influences. Connecting such novel properties of $5-\mathrm{HT}_{2 \mathrm{~A}} \mathrm{Rs}$ to distinct functional consequences of 5-HT-, or agonist-, specific activation of the $5-\mathrm{HT}_{2 \mathrm{~A}} \mathrm{Rs}$ will be important for improving understanding the myriad influences of $5-\mathrm{HT}_{2 \mathrm{~A}} \mathrm{Rs}$ in the CNS. The development of highly selective $5-\mathrm{HT}_{2 \mathrm{~A}} \mathrm{R}$ ligands will be essential for further establishing the critical involvement of the $5-\mathrm{HT}_{2 \mathrm{~A}} \mathrm{R}$ for a number of fundamental cognitive behaviors.

\section{References}

Abbas, A. I., Yadav, P. N., Yao, W. D., Arbuckle, M. I., Grant, S. G., Caron, M. G., et al. (2009). PSD-95 is essential for hallucinogen and atypical antipsychotic drug actions at serotonin receptors. J. Neurosci. 29, 7124-7136. doi: 10.1523/JNEUROSCI.1090-09.2009

Adriaens, A. M., Polis, I. E., Vermeire, S. T., Waelbers, T., Duchateau, L., Sys, S. U., et al. (2012). The influence of morphine on cerebral 5-HT2A availability in dogs: a SPECT study. J. Nucl. Med. 53, 1969-1973. doi: 10.2967/jnumed.112.103796

Aghajanian, G. K., and Marek, G. J. (1999). Serotonin, via 5-HT2A receptors, increases EPSCs in layer $\mathrm{V}$ pyramidal cells of prefrontal cortex by an asynchronous mode of glutamate release. Brain Res. 825, 161-171. doi: 10.1016/S0006-8993(99)01224-X

Alfimova, M. V., Monakhov, M. V., Abramova, L. I., Golubev, S. A., and Golimbet, V. E. (2009). [Serotonin receptor (5-HTR2A) and dysbindin (DTNBP1) genes and component process variables of short-term verbal memory in schizophrenia]. Zh. Nevrol. Psikhiatr. Im. S.S Korsakova 109, 70-75.

Alhaider, A. A., Ageel, A. M., and Ginawi, O. T. (1993). The quipazine- and TFMPP-increased conditioned avoidance response in rats: role of 5HT1C/5HT2 receptors. Neuropharmacology 32, 1427-1432. doi: 10.1016/00283908(93)90040-A

Aloyo, V. J., and Harvey, J. A. (2000). Antagonist binding at 5-HT(2A) and $5-\mathrm{HT}(2 \mathrm{C})$ receptors in the rabbit: high correlation with the profile for the human receptors. Eur. J. Pharmacol. 406, 163-169. doi: 10.1016/S0014-2999(00) 00645-2

Amodeo, D. A., Jones, J. H., Sweeney, J. A., and Ragozzino, M. E. (2014). Risperidone and the 5-HT2A receptor antagonist M100907 improve probabilistic reversal learning in BTBR T $+\mathrm{tf} / \mathrm{J}$ mice. Autism Res. 7, 555-567. doi: 10.1002/aur.1395

Anagnostaras, S. G., Maren, S., and Fanselow, M. S. (1999). Temporally graded retrograde amnesia of contextual fear after hippocampal damage in rats: withinsubjects examination. J. Neurosci. 19, 1106-1114.

Arvanov, V. L., Liang, X., Magro, P., Roberts, R., and Wang, R. Y. (1999). A pre- and postsynaptic modulatory action of 5-HT and the 5-HT2A, 2C receptor agonist DOB on NMDA-evoked responses in the rat medial prefrontal cortex. Eur. J. Neurosci. 11, 2917-2934. doi: 10.1046/j.1460-9568.1999.00708.x

Auclair, A., Drouin, C., Cotecchia, S., Glowinski, J., and Tassin, J. P. (2004). 5-HT2A and alphalb-adrenergic receptors entirely mediate dopamine release, locomotor response and behavioural sensitization to opiates and psychostimulants. Eur. J. Neurosci. 20, 3073-3084. doi: 10.1111/j.14609568.2004.03805.x

Avesar, D., and Gulledge, A. T. (2012). Selective serotonergic excitation of callosal projection neurons. Front. Neural Circuits 6:12. doi: 10.3389/fncir.2012.00012

Baker, J. D., and Azorlosa, J. L. (1996). The NMDA antagonist MK-801 blocks the extinction of Pavlovian fear conditioning. Behav. Neurosci. 110, 618-620. doi: 10.1037/0735-7044.110.3.618

Bekinschtein, P., Renner, M. C., Gonzalez, M. C., and Weisstaub, N. (2013). Role of medial prefrontal cortex serotonin $2 \mathrm{~A}$ receptors in the control of retrieval of recognition memory in rats. J. Neurosci. 33, 15716-15725. doi: 10.1523/JNEUROSCI.2087-13.2013

Berg, K. A., Harvey, J. A., Spampinato, U., and Clarke, W. P. (2008). Physiological and therapeutic relevance of constitutive activity of 5-HT 2A and 5-HT 2C receptors for the treatment of depression. Prog. Brain Res. 172, 287-305. doi: 10.1016/S0079-6123(08)00914-X

Bhagwagar, Z., Hinz, R., Taylor, M., Fancy, S., Cowen, P., and Grasby, P. (2006). Increased 5-HT(2A) receptor binding in euthymic, medication-free patients

\section{Acknowledgments}

This project was supported by the NSF (IBN 0630522) and $\mathrm{NIH}$ (MH 086591) and a Researcher of the Year award from the Division of Research at Florida Atlantic University to RS and National Natural Science Foundation general projects from China (81271217, 81471161), Ph.D. Start Fund from Anhui Medical University (XJ201405) to GZ.

recovered from depression: a positron emission study with [(11)C]MDL 100,907. Am. J. Psychiatry 163, 1580-1587.

Bhatnagar, A., Sheffler, D. J., Kroeze, W. K., Compton-Toth, B., and Roth, B. L. (2004). Caveolin-1 interacts with 5-HT2A serotonin receptors and profoundly modulates the signaling of selected Galphaq-coupled protein receptors. J. Biol. Chem. 279, 34614-34623. doi: 10.1074/jbc.M404673200

Blanchard, R. J., and Blanchard, D. C. (1969). Passive and active reactions to fear-eliciting stimuli. J. Comp. Physiol. Psychol. 68, 129-135. doi: 10.1037/h00 27676

Blasi, G., De Virgilio, C., Papazacharias, A., Taurisano, P., Gelao, B., Fazio, L., et al. (2013). Converging evidence for the association of functional genetic variation in the serotonin receptor 2a gene with prefrontal function and olanzapine treatment. JAMA Psychiatry 70, 921-930. doi: 10.1001/jamapsychiatry.2013.1378

Bombardi, C. (2012). Neuronal localization of 5-HT2A receptor immunoreactivity in the rat hippocampal region. Brain Res. Bull. 87, 259-273. doi: 10.1016/j.brainresbull.2011.11.0068

Bombardi, C. (2014). Neuronal localization of the 5-HT2 receptor family in the amygdaloid complex. Front. Pharmacol. 5:68. doi: 10.3389/fphar.2014.0006

Boulougouris, V., Glennon, J. C., and Robbins, T. W. (2008). Dissociable effects of selective 5-HT2A and 5-HT2C receptor antagonists on serial spatial reversal learning in rats. Neuropsychopharmacology 33, 2007-2019. doi: 10.1038/sj.npp.1301584

Brea, J., Castro, M., Giraldo, J., Lopez-Gimenez, J. F., Padin, J. F., Quintian, F., et al. (2009). Evidence for distinct antagonist-revealed functional states of 5hydroxytryptamine(2A) receptor homodimers. Mol. Pharmacol. 75, 1380-1391. doi: 10.1124/mol.108.054395

Broadbent, N. J., Squire, L. R., and Clark, R. E. (2004). Spatial memory, recognition memory, and the hippocampus. Proc. Natl. Acad. Sci. U.S.A. 101, 14515-14520. doi: 10.1073/pnas.0406344101

Buchborn, T., Schroder, H., Hollt, V., and Grecksch, G. (2014). Repeated lysergic acid diethylamide in an animal model of depression: normalisation of learning behaviour and hippocampal serotonin 5-HT2 signalling. J. Psychopharmacol. 28, 545-552. doi: 10.1177/0269881114531666

Burnet, P. W., Eastwood, S. L., Lacey, K., and Harrison, P. J. (1995). The distribution of 5-HT1A and 5-HT2A receptor mRNA in human brain. Brain Res. 676, 157-168. doi: 10.1016/0006-8993(95)00104-X

Carr, M. F., Jadhav, S. P., and Frank, L. M. (2011). Hippocampal replay in the awake state: a potential substrate for memory consolidation and retrieval. Nat. Neurosci. 14, 147-153. doi: 10.1038/nn.2732

Carter, O. L., Burr, D. C., Pettigrew, J. D., Wallis, G. M., Hasler, F., and Vollenweider, F. X. (2005). Using psilocybin to investigate the relationship between attention, working memory, and the serotonin $1 \mathrm{~A}$ and $2 \mathrm{~A}$ receptors. J. Cogn. Neurosci. 17, 1497-1508. doi: 10.1162/089892905774597191

Catlow, B. J., Song, S., Paredes, D. A., Kirstein, C. L., and Sanchez-Ramos, J. (2013). Effects of psilocybin on hippocampal neurogenesis and extinction of trace fear conditioning. Exp. Brain Res. 228, 481-491. doi: 10.1007/s00221-0133579-0

Celada, P., Puig, M. V., Diaz-Mataix, L., and Artigas, F. (2008). The hallucinogen DOI reduces low-frequency oscillations in rat prefrontal cortex: reversal by antipsychotic drugs. Biol. Psychiatry 64, 392-400. doi: 10.1016/j.biopsych.2008.03.013

Chen, A., Hough, C. J., and Li, H. (2003). Serotonin type II receptor activation facilitates synaptic plasticity via N-methyl-D-aspartate-mediated mechanism in the rat basolateral amygdala. Neuroscience 119, 53-63. doi: 10.1016/S03064522(03)00076-9 
Cho, Y. H., Friedman, E., and Silva, A. J. (1999). Ibotenate lesions of the hippocampus impair spatial learning but not contextual fear conditioning in mice. Behav. Brain Res. 98, 77-87. doi: 10.1016/S0166-4328(98)00054-0

Chowdhury, N., Quinn, J. J., and Fanselow, M. S. (2005). Dorsal hippocampus involvement in trace fear conditioning with long, but not short, trace intervals in mice. Behav. Neurosci. 119, 1396-1402. doi: 10.1037/0735-7044.119.5.1396

Christensen, R., Marcussen, A. B., Wortwein, G., Knudsen, G. M., and Aznar, S. (2008). Abeta(1-42) injection causes memory impairment, lowered cortical and serum BDNF levels, and decreased hippocampal 5-HT(2A) levels. Exp. Neurol. 210, 164-171. doi: 10.1016/j.expneurol.2007.10.009

Chrobak, J. J., and Buzsaki, G. (1996). High-frequency oscillations in the output networks of the hippocampal- entorhinal axis of the freely behaving rat. J. Neurosci. 16, 3056-3066.

Clark, R. E., and Squire, L. R. (1998). Classical conditioning and brain systems: the role of awareness. Science 280, 77-81. doi: 10.1126/science.280.5360.77

Cohen, H. (2005). Anxiolytic effect and memory improvement in rats by antisense oligodeoxynucleotide to 5-hydroxytryptamine-2A precursor protein. Depress. Anxiety 22, 84-93. doi: 10.1002/da.20087

Cohen, S. J., Munchow, A. H., Rios, L. M., Zhang, G., Asgeirsdottir, H. N., and Stackman, R. W. Jr. (2013). The rodent hippocampus is essential for nonspatial object memory. Curr. Biol. 23, 1685-1690. doi: 10.1016/j.cub.2013.07.002

Cohen, S. J., and Stackman, R. W. Jr. (2015). Assessing rodent hippocampal involvement in the novel object recognition task. A review. Behav. Brain Res. 285, 105-117. doi: 10.1016/j.bbr.2014.08.002

Conn, P. J., Christopoulos, A., and Lindsley, C. W. (2009). Allosteric modulators of GPCRs: a novel approach for the treatment of CNS disorders. Nat. Rev. Drug Discov. 8, 41-54. doi: 10.1038/nrd2760

Cornea-Hebert, V., Riad, M., Wu, C., Singh, S. K., and Descarries, L. (1999). Cellular and subcellular distribution of the serotonin 5-HT2A receptor in the central nervous system of adult rat. J. Comp. Neurol. 409, 187-209. doi: 10.1002/(SICI)1096-9861(19990628)409:2<187::AID-CNE2>3.0. $\mathrm{CO} ; 2-\mathrm{P}$

Cornea-Hebert, V., Watkins, K. C., Roth, B. L., Kroeze, W. K., Gaudreau, P., Leclerc, N., et al. (2002). Similar ultrastructural distribution of the 5$\mathrm{HT}(2 \mathrm{~A})$ serotonin receptor and microtubule-associated protein MAP1A in cortical dendrites of adult rat. Neuroscience 113, 23-35. doi: 10.1016/S03064522(02)00146-X

Dai, Y., Dudek, N. L., Patel, T. B., and Muma, N. A. (2008). Transglutaminasecatalyzed transamidation: a novel mechanism for Racl activation by 5 hydroxytryptamine2A receptor stimulation. J. Pharmacol. Exp. Ther. 326, 153-162. doi: 10.1124/jpet.107.135046

Day, M., Olson, P. A., Platzer, J., Striessnig, J., and Surmeier, D. J. (2002). Stimulation of 5-HT(2) receptors in prefrontal pyramidal neurons inhibits $\mathrm{Ca}(\mathrm{v}) 1.2 \mathrm{~L}$ type $\mathrm{Ca}(2+)$ currents via a PLCbeta/IP3/calcineurin signaling cascade. J. Neurophysiol. 87, 2490-2504.

de Quervain, D. J., Henke, K., Aerni, A., Coluccia, D., Wollmer, M. A., Hock, C., et al. (2003). A functional genetic variation of the 5-HT2a receptor affects human memory. Nat. Neurosci. 6, 1141-1142. doi: 10.1038/nn1146

Egan, C., Herrick-Davis, K., and Teitler, M. (1998). Creation of a constitutively activated state of the 5-HT2A receptor by site-directed mutagenesis: revelation of inverse agonist activity of antagonists. Ann. N. Y. Acad. Sci. 861, 136-139. doi: 10.1111/j.1749-6632.1998.tb10184.x

Eichenbaum, H. (1999). The hippocampus and mechanisms of declarative memory. Behav. Brain Res. 103, 123-133. doi: 10.1016/S0166-4328(99) 00044-3

Eichenbaum, H. (2004). Hippocampus: cognitive processes and neural representations that underlie declarative memory. Neuron 44, 109-120. doi: 10.1016/j.neuron.2004.08.028

Ennaceur, A. (2010). One-trial object recognition in rats and mice: methodological and theoretical issues. Behav. Brain Res. 215, 244-254. doi: 10.1016/j.bbr.2009.12.036

Fedotova, Y. O., and Ordyan, N. E. (2010). Blockade of 5-HT2A/2C-type receptors impairs learning in female rats in the course of estrous cycle. Bull. Exp. Biol. Med. 150, 6-8. doi: 10.1007/s10517-010-1053-6

Fletcher, P. J., Grottick, A. J., and Higgins, G. A. (2002). Differential effects of the 5-HT(2A) receptor antagonist M100907 and the 5-HT(2C) receptor antagonist SB242084 on cocaine-induced locomotor activity, cocaine self-administration and cocaine-induced reinstatement of responding. Neuropsychopharmacology 27, 576-586.

Fletcher, P. J., Rizos, Z., Noble, K., Soko, A. D., Silenieks, L. B., Le, A. D., et al. (2012). Effects of the 5-HT2C receptor agonist Ro600175 and the 5-HT2A receptor antagonist M100907 on nicotine selfadministration and reinstatement. Neuropharmacology 62, 2288-2298. doi: 10.1016/j.neuropharm.2012.01.023

Florian, J. A., and Watts, S. W. (1998). Integration of mitogen-activated protein kinase kinase activation in vascular 5-hydroxytryptamine2A receptor signal transduction. J. Pharmacol. Exp. Ther. 284, 346-355.

Frick, L. R., Bernardez-Vidal, M., Hocht, C., Zanutto, B. S., and Rapanelli, M. (2015). Dual role of serotonin in the acquisition and extinction of reward-driven learning: involvement of 5-HT1A, 5-HT2A and 5-HT3 receptors. Behav. Brain Res. 277, 193-203. doi: 10.1016/j.bbr.2014.06.025

Furr, A., Lapiz-Bluhm, M. D., and Morilak, D. A. (2012). 5-HT2A receptors in the orbitofrontal cortex facilitate reversal learning and contribute to the beneficial cognitive effects of chronic citalopram treatment in rats. Int. J. Neuropsychopharmacol. 15, 1295-1305. doi: 10.1017/S1461145711001441

Gaddum, J. H., and Picarelli, Z. P. (1957). Two kinds of tryptamine receptor. Br. J. Pharmacol. Chemother. 12, 323-328. doi: 10.1111/j.1476-5381.1957.tb00142.x

Gimpl, M. P., Gormezano, I., and Harvey, J. A. (1979). Effects of LSD on learning as measured by classical conditioning of the rabbit nictitating membrane response. J. Pharmacol. Exp. Ther. 208, 330-334.

Glebov, K., Lochner, M., Jabs, R., Lau, T., Merkel, O., Schloss, P., et al. (2015). Serotonin stimulates secretion of exosomes from microglia cells. Glia 63, 626-634. doi: 10.1002/glia.22772

Gong, P., Li, J., Wang, J., Lei, X., Chen, D., Zhang, K., et al. (2011). Variations in 5HT2A influence spatial cognitive abilities and working memory. Can. J. Neurol. Sci. 38, 303-308. doi: 10.1017/S0317167100011513

Gonzalez-Maeso, J., Ang, R. L., Yuen, T., Chan, P., Weisstaub, N. V., LopezGimenez, J. F., et al. (2008). Identification of a serotonin/glutamate receptor complex implicated in psychosis. Nature 452, 93-97. doi: 10.1038/nature 06612

Gonzalez-Maeso, J., Weisstaub, N. V., Zhou, M., Chan, P., Ivic, L., Ang, R., et al. (2007). Hallucinogens recruit specific cortical 5-HT(2A) receptormediated signaling pathways to affect behavior. Neuron 53, 439-452. doi: 10.1016/j.neuron.2007.01.008

Gooz, M., Gooz, P., Luttrell, L. M., and Raymond, J. R. (2006). 5-HT2A receptor induces ERK phosphorylation and proliferation through ADAM17 tumor necrosis factor-alpha-converting enzyme (TACE) activation and heparin-bound epidermal growth factor-like growth factor (HB-EGF) shedding in mesangial cells. J. Biol. Chem. 281, 21004-21012. doi: 10.1074/jbc.M512 096200

Gray, J. A., Bhatnagar, A., Gurevich, V. V., and Roth, B. L. (2003). The interaction of a constitutively active arrestin with the arrestin-insensitive 5-HT(2A) receptor induces agonist-independent internalization. Mol. Pharmacol. 63, 961-972. doi: 10.1124/mol.63.5.961

Grob, C. S., Danforth, A. L., Chopra, G. S., Hagerty, M., Mckay, C. R., Halberstadt, A. L., et al. (2011). Pilot study of psilocybin treatment for anxiety in patients with advanced-stage cancer. Arch. Gen. Psychiatry 68, 71-78. doi: 10.1001/archgenpsychiatry.2010.116

Gulati, A., and Bhargava, H. N. (1989). Brain and spinal cord 5-HT2 receptors of morphine-tolerant-dependent and -abstinent rats. Eur. J. Pharmacol. 167, 185-192. doi: 10.1016/0014-2999(89)90578-5

Hagberg, G. B., Blomstrand, F., Nilsson, M., Tamir, H., and Hansson, E. (1998). Stimulation of 5-HT2A receptors on astrocytes in primary culture opens voltage-independent Ca2+ channels. Neurochem. Int. 32, 153-162. doi: 10.1016/S0197-0186(97)00087-9

Hannon, J., and Hoyer, D. (2008). Molecular biology of 5-HT receptors. Behav. Brain Res. 195, 198-213. doi: 10.1016/j.bbr.2008.03.020

Hasselbalch, S. G., Madsen, K., Svarer, C., Pinborg, L. H., Holm, S., Paulson, O. B., et al. (2008). Reduced 5-HT2A receptor binding in patients with mild cognitive impairment. Neurobiol. Aging 29, 1830-1838. doi: 10.1016/j.neurobiolaging.2007.04.011

Hasuo, H., Matsuoka, T., and Akasu, T. (2002). Activation of presynaptic 5hydroxytryptamine $2 \mathrm{~A}$ receptors facilitates excitatory synaptic transmission via protein kinase C in the dorsolateral septal nucleus. J. Neurosci. 22, 7509-7517. 
Herry, C., Ciocchi, S., Senn, V., Demmou, L., Muller, C., and Luthi, A. (2008). Switching on and off fear by distinct neuronal circuits. Nature 454, 600-606. doi: $10.1038 /$ nature07166

Herry, C., Ferraguti, F., Singewald, N., Letzkus, J. J., Ehrlich, I., and Luthi, A. (2010). Neuronal circuits of fear extinction. Eur. J. Neurosci. 31, 599-612. doi: 10.1111/j.1460-9568.2010.07101.x

Homberg, J. R. (2012). Serotonin and decision making processes. Neurosci. Biobehav. Rev. 36, 218-236. doi: 10.1016/j.neubiorev.2011.06.001

Hoyer, D., Hannon, J. P., and Martin, G. R. (2002). Molecular, pharmacological and functional diversity of 5-HT receptors. Pharmacol. Biochem. Behav. 71, 533-554. doi: 10.1016/S0091-3057(01)00746-8

Hoyer, D., Pazos, A., Probst, A., and Palacios, J. M. (1986). Serotonin receptors in the human brain. II. Characterization and autoradiographic localization of 5HT1C and 5-HT2 recognition sites. Brain Res. 376, 97-107. doi: 10.1016/00068993(86)90903-0

Huerta, P. T., Sun, L. D., Wilson, M. A., and Tonegawa, S. (2000). Formation of temporal memory requires NMDA receptors within CA1 pyramidal neurons. Neuron 25, 473-480. doi: 10.1016/S0896-6273(00)80909-5

Izumi, T., Ohmura, Y., Futami, Y., Matsuzaki, H., Kubo, Y., Yoshida, T., et al. (2012). Effects of serotonergic terminal lesion in the amygdala on conditioned fear and innate fear in rats. Eur. J. Pharmacol. 696, 89-95. doi: 10.1016/j.ejphar.2012.09.028

Jakab, R. L., and Goldman-Rakic, P. S. (1998). 5-Hydroxytryptamine2A serotonin receptors in the primate cerebral cortex: possible site of action of hallucinogenic and antipsychotic drugs in pyramidal cell apical dendrites. Proc. Natl. Acad. Sci. U.S.A. 95, 735-740. doi: 10.1073/pnas.95.2.735

Jenkins, T. A., Elliott, J. J., Ardis, T. C., Cahir, M., Reynolds, G. P., Bell, R., et al. (2009). Tryptophan depletion impairs object-recognition memory in the rat: reversal by risperidone. Behav. Brain Res. 208, 479-483. doi: 10.1016/j.bbr.2009.12.030

Jiang, X., Xing, G., Yang, C., Verma, A., Zhang, L., and Li, H. (2009). Stress impairs 5-HT2A receptor-mediated serotonergic facilitation of GABA release in juvenile rat basolateral amygdala. Neuropsychopharmacology 34, 410-423. doi: 10.1038/npp.2008.71

Jones, K. A., Srivastava, D. P., Allen, J. A., Strachan, R. T., Roth, B. L., and Penzes, P. (2009). Rapid modulation of spine morphology by the 5-HT2A serotonin receptor through kalirin-7 signaling. Proc. Natl. Acad. Sci. U.S.A. 106, 19575-19580. doi: 10.1073/pnas.0905884106

Jovanovic, T., and Ressler, K. J. (2010). How the neurocircuitry and genetics of fear inhibition may inform our understanding of PTSD. Am. J. Psychiatry 167, 648-662. doi: 10.1176/appi.ajp.2009.09071074

Julius, D., Huang, K. N., Livelli, T. J., Axel, R., and Jessell, T. M. (1990). The 5HT2 receptor defines a family of structurally distinct but functionally conserved serotonin receptors. Proc. Natl. Acad. Sci. U.S.A. 87, 928-932. doi: 10.1073/pnas.87.3.928

Kandel, E. R., and Squire, L. R. (2000). Neuroscience: breaking down scientific barriers to the study of brain and mind. Science 290, 1113-1120. doi: 10.1126/science.290.5494.1113

Kant, G. J., Wylie, R. M., Chu, K., and Ghosh, S. (1998). Effects of the serotonin agonists 8-OH-DPAT, buspirone, and DOI on water maze performance. Pharmacol. Biochem. Behav. 59, 729-735. doi: 10.1016/S0091-3057(97)0 0553-4

Karlsson, M. P., and Frank, L. M. (2009). Awake replay of remote experiences in the hippocampus. Nat. Neurosci. 12, 913-918. doi: 10.1038/nn.2344

Khaliq, S., Haider, S., Ahmed, S. P., Perveen, T., and Haleem, D. J. (2006). Relationship of brain tryptophan and serotonin in improving cognitive performance in rats. Pak. J. Pharm. Sci. 19, 11-15.

Kim, J. J., and Fanselow, M. S. (1992). Modality-specific retrograde amnesia of fear. Science 256, 675-677. doi: 10.1126/science.1585183

Kometer, M., Schmidt, A., Jancke, L., and Vollenweider, F. X. (2013). Activation of serotonin $2 \mathrm{~A}$ receptors underlies the psilocybin-induced effects on alpha oscillations, N170 visual-evoked potentials, and visual hallucinations. J. Neurosci. 33, 10544-10551. doi: 10.1523/JNEUROSCI.300712.2013

Kroeze, W. K., and Roth, B. L. (1998). The molecular biology of serotonin receptors: therapeutic implications for the interface of mood and psychosis. Biol. Psychiatry 44, 1128-1142. doi: 10.1016/S0006-3223(98) 00132-2
Kurrasch-Orbaugh, D. M., Parrish, J. C., Watts, V. J., and Nichols, D. E. (2003a). A complex signaling cascade links the serotonin2A receptor to phospholipase A2 activation: the involvement of MAP kinases. J. Neurochem. 86, 980-991. doi: 10.1046/j.1471-4159.2003.01921.x

Kurrasch-Orbaugh, D. M., Watts, V. J., Barker, E. L., and Nichols, D. E. (2003b). Serotonin 5-hydroxytryptamine $2 \mathrm{~A}$ receptor-coupled phospholipase $\mathrm{C}$ and phospholipase A2 signaling pathways have different receptor reserves. J. Pharmacol. Exp. Ther. 304, 229-237. doi: 10.1124/jpet.102.042184

Ledgerwood, L., Richardson, R., and Cranney, J. (2003). Effects of D-cycloserine on extinction of conditioned freezing. Behav. Neurosci. 117, 341-349. doi: 10.1037/0735-7044.117.2.341

Levkovitz, Y., Ophir-Shaham, O., Bloch, Y., Treves, I., Fennig, S., and Grauer, E. (2003). Effect of L-tryptophan on memory in patients with schizophrenia. J. Nerv. Ment. Dis. 191, 568-573. doi: 10.1097/01.nmd.0000087182.29781.e0

Li, J. X., Shah, A. P., Patel, S. K., Rice, K. C., and France, C. P. (2013). Modification of the behavioral effects of morphine in rats by serotonin 5HT(1)A and 5-HT(2)A receptor agonists: antinociception, drug discrimination, and locomotor activity. Psychopharmacology (Berl) 225, 791-801. doi: 10.1007/s00213-012-2870-2

Li, L. B., Zhang, L., Sun, Y. N., Han, L. N., Wu, Z. H., Zhang, Q. J., et al. (2015). Activation of serotonin2A receptors in the medial septum-diagonal band of Broca complex enhanced working memory in the hemiparkinsonian rats. Neuropharmacology 91, 23-33. doi: 10.1016/j.neuropharm.2014.11.025

Lopez-Gimenez, J. F., Vilaro, M. T., Palacios, J. M., and Mengod, G. (1998). [3H]MDL 100,907 labels 5-HT2A serotonin receptors selectively in primate brain. Neuropharmacology 37, 1147-1158. doi: 10.1016/S0028-3908(98)00102-6

Lukasiewicz, S., Polit, A., Kedracka-Krok, S., Wedzony, K., Mackowiak, M., and Dziedzicka-Wasylewska, M. (2010). Hetero-dimerization of serotonin 5HT(2A) and dopamine D(2) receptors. Biochim. Biophys. Acta 1803, 1347-1358. doi: 10.1016/j.bbamcr.2010.08.010

Luttgen, M., Ove Ogren, S., and Meister, B. (2004). Chemical identity of 5HT2A receptor immunoreactive neurons of the rat septal complex and dorsal hippocampus. Brain Res. 1010, 156-165. doi: 10.1016/j.brainres.2004.03.016

Marner, L., Frokjaer, V. G., Kalbitzer, J., Lehel, S., Madsen, K., Baare, W. F., et al. (2012). Loss of serotonin $2 \mathrm{~A}$ receptors exceeds loss of serotonergic projections in early Alzheimer's disease: a combined [(11)C]DASB and $[(18)$ F] altanserin-PET study. Neurobiol. Aging 33, 479-487. doi: 10.1016/j.neurobiolaging.2010.03.023

Marner, L., Knudsen, G. M., Madsen, K., Holm, S., Baare, W., and Hasselbalch, S. G. (2011). The reduction of baseline serotonin $2 \mathrm{~A}$ receptors in mild cognitive impairment is stable at two-year follow-up. J. Alzheimers Dis. 23, 453-459.

Masson, J., Emerit, M. B., Hamon, M., and Darmon, M. (2012). Serotonergic signaling: multiple effectors and pleiotropic effects. Wiley Interdiscip. Rev. Membr. Transp. Signal. 1, 685-713. doi: 10.1002/wmts.50

Matus-Amat, P., Higgins, E. A., Barrientos, R. M., and Rudy, J. W. (2004). The role of the dorsal hippocampus in the acquisition and retrieval of context memory representations. J. Neurosci. 24, 2431-2439. doi: 10.1523/JNEUROSCI.159803.2004

McEchron, M. D., Bouwmeester, H., Tseng, W., Weiss, C., and Disterhoft, J. F. (1998). Hippocampectomy disrupts auditory trace fear conditioning and contextual fear conditioning in the rat. Hippocampus 8, 638-646. doi: 10.1002/(SICI)1098-1063(1998)8:6<638::AID-HIPO6>3.0.CO;2-Q

McHugh, T. J., Blum, K. I., Tsien, J. Z., Tonegawa, S., and Wilson, M. A. (1996). Impaired hippocampal representation of space in CA1-specific NMDAR1 knockout mice. Cell 87, 1339-1349. doi: 10.1016/S0092-8674(00)81828-0

McLean, J. H., Darby-King, A., and Hodge, E. (1996). 5-HT2 receptor involvement in conditioned olfactory learning in the neonate rat pup. Behav. Neurosci. 110, 1426-1434. doi: 10.1037/0735-7044.110.6.1426

Melancon, B. J., Hopkins, C. R., Wood, M. R., Emmitte, K. A., Niswender, C. M., Christopoulos, A., et al. (2012). Allosteric modulation of seven transmembrane spanning receptors: theory, practice, and opportunities for central nervous system drug discovery. J. Med. Chem. 55, 1445-1464. doi: 10.1021/jm20 $1139 \mathrm{r}$

Meller, R., Harrison, P. J., Elliott, J. M., and Sharp, T. (2002). In vitro evidence that 5-hydroxytryptamine increases efflux of glial glutamate via 5-HT(2A) receptor activation. J. Neurosci. Res. 67, 399-405. doi: 10.1002/jnr.10126

Meltzer, C. C., Smith, G., Dekosky, S. T., Pollock, B. G., Mathis, C. A., Moore, R. Y., et al. (1998). Serotonin in aging, late-life depression, and Alzheimer's 
disease: the emerging role of functional imaging. Neuropsychopharmacology 18 , 407-430. doi: 10.1016/S0893-133X(97)00194-2

Meltzer, H. Y. (1999). The role of serotonin in antipsychotic drug action. Neuropsychopharmacology 21, 106S-115S. doi: 10.1016/S0893-133X(99) 00046-9

Meneses, A. (2007). Stimulation of 5-HT1A, 5-HT1B, 5-HT2A/2C, 5-HT3 and 5-HT4 receptors or 5-HT uptake inhibition: short- and long-term memory. Behav. Brain Res. 184, 81-90. doi: 10.1016/j.bbr.2007.06.026

Meneses, A. (2013). 5-HT systems: emergent targets for memory formation and memory alteration. Rev. Neurosci. 24, 629-664. doi: 10.1515/revneuro2013-0026

Meneses, A., Terron, J. A., and Hong, E. (1997). Effects of the 5-HT receptor antagonists GR127935 (5-HT1B/1D) and MDL100907 (5-HT2A) in the consolidation of learning. Behav. Brain Res. 89, 217-223. doi: 10.1016/S01664328(97)00055-7

Millan, M. J., Marin, P., Bockaert, J., and Mannoury La Cour, C. (2008). Signaling at G-protein-coupled serotonin receptors: recent advances and future research directions. Trends Pharmacol. Sci. 29, 454-464. doi: 10.1016/j.tips.2008.06.007

Miner, L. A., Backstrom, J. R., Sanders-Bush, E., and Sesack, S. R. (2003). Ultrastructural localization of serotonin2A receptors in the middle layers of the rat prelimbic prefrontal cortex. Neuroscience 116, 107-117. doi: 10.1016/S03064522(02)00580-8

Mirjana, C., Baviera, M., Invernizzi, R. W., and Balducci, C. (2004). The serotonin 5-HT2A receptors antagonist M100907 prevents impairment in attentional performance by NMDA receptor blockade in the rat prefrontal cortex. Neuropsychopharmacology 29, 1637-1647. doi: 10.1038/sj.npp.1300479

Morris, R. (1984). Developments of a water-maze procedure for studying spatial learning in the rat. J. Neurosci. Methods 11, 47-60. doi: 10.1016/01650270(84)90007-4

Morris, R. G., Garrud, P., Rawlins, J. N., and O’keefe, J. (1982). Place navigation impaired in rats with hippocampal lesions. Nature 297, 681-683. doi: 10.1038/297681a0

Moser, E. I., Kropff, E., and Moser, M. B. (2008). Place cells, grid cells, and the brain's spatial representation system. Annu. Rev. Neurosci. 31, 69-89. doi: 10.1146/annurev.neuro.31.061307.090723

Naghdi, N., and Harooni, H. E. (2005). The effect of intrahippocampal injections of ritanserin (5HT2A/2C antagonist) and granisetron (5HT3 antagonist) on learning as assessed in the spatial version of the water maze. Behav. Brain Res. 157, 205-210. doi: 10.1016/j.bbr.2004.06.024

Nic Dhonnchadha, B. A., Fox, R. G., Stutz, S. J., Rice, K. C., and Cunningham, K. A. (2009). Blockade of the serotonin 5-HT2A receptor suppresses cue-evoked reinstatement of cocaine-seeking behavior in a rat self-administration model. Behav. Neurosci. 123, 382-396. doi: 10.1037/a0014592

O’Neill, M. F., Heron-Maxwell, C. L., and Shaw, G. (1999). 5-HT2 receptor antagonism reduces hyperactivity induced by amphetamine, cocaine, and MK801 but not D1 agonist C-APB. Pharmacol. Biochem. Behav. 63, 237-243. doi: 10.1016/S0091-3057(98)00240-8

Pazos, A., Probst, A., and Palacios, J. M. (1987). Serotonin receptors in the human brain-IV. Autoradiographic mapping of serotonin-2 receptors. Neuroscience 21, 123-139. doi: 10.1016/0306-4522(87)90327-7

Peddie, C. J., Davies, H. A., Colyer, F. M., Stewart, M. G., and Rodriguez, J. J. (2008). Colocalisation of serotonin2A receptors with the glutamate receptor subunits NR1 and GluR2 in the dentate gyrus: an ultrastructural study of a modulatory role. Exp. Neurol. 211, 561-573. doi: 10.1016/j.expneurol.2008.03.003

Perani, D., Garibotto, V., Gorini, A., Moresco, R. M., Henin, M., Panzacchi, A., et al. (2008). In vivo PET study of $5 \mathrm{HT}(2 \mathrm{~A})$ serotonin and $\mathrm{D}(2)$ dopamine dysfunction in drug-naive obsessive-compulsive disorder. Neuroimage 42, 306314. doi: 10.1016/j.neuroimage.2008.04.233

Peroutka, S. J., and Snyder, S. H. (1979). Multiple serotonin receptors: differential binding of $[3 \mathrm{H}] 5$-hydroxytryptamine, $[3 \mathrm{H}]$ lysergic acid diethylamide and [3H] spiroperidol. Mol. Pharmacol. 16, 687-699.

Phillips, R. G., and LeDoux, J. E. (1992). Differential contribution of amygdala and hippocampus to cued and contextual fear conditioning. Behav. Neurosci. 106, 274-285. doi: 10.1037/0735-7044.106.2.274

Pockros, L. A., Pentkowski, N. S., Swinford, S. E., and Neisewander, J. L. (2011). Blockade of 5-HT2A receptors in the medial prefrontal cortex attenuates reinstatement of cue-elicited cocaine-seeking behavior in rats. Psychopharmacology (Berl) 213, 307-320. doi: 10.1007/s00213-010-2071-9
Porter, R. J., Lunn, B. S., and O'brien, J. T. (2003). Effects of acute tryptophan depletion on cognitive function in Alzheimer's disease and in the healthy elderly. Psychol. Med. 33, 41-49. doi: 10.1017/s0033291702006906

Poyurovsky, M., Koren, D., Gonopolsky, I., Schneidman, M., Fuchs, C., Weizman, A., et al. (2003). Effect of the 5-HT2 antagonist mianserin on cognitive dysfunction in chronic schizophrenia patients: an add-on, doubleblind placebo-controlled study. Eur. Neuropsychopharmacol. 13, 123-128. doi: 10.1016/S0924-977X(02)00155-4

Preston, A. R., and Eichenbaum, H. (2013). Interplay of hippocampus and prefrontal cortex in memory. Curr. Biol. 23, R764-R773. doi: 10.1016/j.cub.2013.05.041

Pritchett, D. B., Bach, A. W., Wozny, M., Taleb, O., Dal Toso, R., Shih, J. C., et al. (1988). Structure and functional expression of cloned rat serotonin 5HT-2 receptor. $E M B O ~ J .7,4135-4140$.

Quinn, J. C., Johnson-Farley, N. N., Yoon, J., and Cowen, D. S. (2002). Activation of extracellular-regulated kinase by 5 -hydroxytryptamine(2A) receptors in PC12 cells is protein kinase $\mathrm{C}$-independent and requires calmodulin and tyrosine kinases. J. Pharmacol. Exp. Ther. 303, 746-752. doi: 10.1124/jpet.102.038083

Quirion, R., Richard, J., and Dam, T. V. (1985). Evidence for the existence of serotonin type- 2 receptors on cholinergic terminals in rat cortex. Brain Res. 333 , 345-349. doi: 10.1016/0006-8993(85)91590-2

Quirk, G. J., Pare, D., Richardson, R., Herry, C., Monfils, M. H., Schiller, D., et al. (2010). Erasing fear memories with extinction training. J. Neurosci. 30, 14993-14997. doi: 10.1523/JNEUROSCI.4268-1 0.2010

Rambousek, L., Palenicek, T., Vales, K., and Stuchlik, A. (2014). The effect of psilocin on memory acquisition, retrieval, and consolidation in the rat. Front. Behav. Neurosci. 8:180. doi: 10.3389/fnbeh.2014.00180

Rios, C. D., Jordan, B. A., Gomes, I., and Devi, L. A. (2001). G-protein-coupled receptor dimerization: modulation of receptor function. Pharmacol. Ther. 92, 71-87. doi: 10.1016/S0163-7258(01)00160-7

Romano, A. G., Quinn, J. L., Li, L., Dave, K. D., Schindler, E. A., Aloyo, V. J., et al. (2010). Intrahippocampal LSD accelerates learning and desensitizes the 5-HT(2A) receptor in the rabbit, Romano et al. Psychopharmacology (Berl) 212, 441-448. doi: 10.1007/s00213-010-2004-7

Roth, B. L., Berry, S. A., Kroeze, W. K., Willins, D. L., and Kristiansen, K. (1998). Serotonin 5-HT2A receptors: molecular biology and mechanisms of regulation. Crit. Rev. Neurobiol. 12, 319-338. doi: 10.1615/CritRevNeurobiol.v12.i4.30

Rudy, J. W., Barrientos, R. M., and O'reilly, R. C. (2002). Hippocampal formation supports conditioning to memory of a context. Behav. Neurosci. 116, 530-538. doi: 10.1037/0735-7044.116.4.530

Rudy, J. W., Huff, N. C., and Matus-Amat, P. (2004). Understanding contextual fear conditioning: insights from a two-process model. Neurosci. Biobehav. Rev. 28, 675-685. doi: 10.1016/j.neubiorev.2004.09.004

Ruotsalainen, S., Sirvio, J., Jakala, P., Puumala, T., Macdonald, E., and Riekkinen, P. Sr. (1997). Differential effects of three 5-HT receptor antagonists on the performance of rats in attentional and working memory tasks. Eur. Neuropsychopharmacol. 7, 99-108. doi: 10.1016/S0924-977X(96) 00389-6

Santhosh, L., Estok, K. M., Vogel, R. S., Tamagnan, G. D., Baldwin, R. M., Mitsis, E. M., et al. (2009). Regional distribution and behavioral correlates of 5-HT(2A) receptors in Alzheimer's disease with [(18)F]deuteroaltanserin and PET. Psychiatry Res. 173, 212-217. doi: 10.1016/j.pscychresns.2009. 03.007

Schmid, C. L., and Bohn, L. M. (2010). Serotonin, but not N-methyltryptamines, activates the serotonin $2 \mathrm{~A}$ receptor via a ss-arrestin2/Src/Akt signaling complex in vivo. J. Neurosci. 30, 13513-13524. doi: 10.1523/JNEUROSCI.166510.2010

Schmid, C. L., Raehal, K. M., and Bohn, L. M. (2008). Agonist-directed signaling of the serotonin $2 \mathrm{~A}$ receptor depends on beta-arrestin-2 interactions in vivo. Proc. Natl. Acad. Sci. U.S.A. 105, 1079-1084. doi: 10.1073/pnas.0708862105

Schmitt, J. A., Wingen, M., Ramaekers, J. G., Evers, E. A., and Riedel, W. J. (2006). Serotonin and human cognitive performance. Curr. Pharm. Des. 12, 2473-2486. doi: $10.2174 / 138161206777698909$

Schott, B. H., Seidenbecher, C. I., Richter, S., Wustenberg, T., Debska-Vielhaber, G., Schubert, H., et al. (2011). Genetic variation of the serotonin 2a receptor affects hippocampal novelty processing in humans. PLOS ONE 6:e15984. doi: 10.1371/journal.pone.0015984 
Sheffler, D. J., Kroeze, W. K., Garcia, B. G., Deutch, A. Y., Hufeisen, S. J., Leahy, P., et al. (2006). p90 ribosomal S6 kinase 2 exerts a tonic brake on G proteincoupled receptor signaling. Proc. Natl. Acad. Sci. U.S.A. 103, 4717-4722. doi: 10.1073/pnas.0600585103

Shi, J., Damjanoska, K. J., Singh, R. K., Carrasco, G. A., Garcia, F., Grippo, A. J., et al. (2007). Agonist induced-phosphorylation of Galphal1 protein reduces coupling to 5-HT2A receptors. J. Pharmacol. Exp. Ther. 323, 248-256. doi: 10.1124/jpet.107.122317

Sierra-Mercado, D., Padilla-Coreano, N., and Quirk, G. J. (2011). Dissociable roles of prelimbic and infralimbic cortices, ventral hippocampus, and basolateral amygdala in the expression and extinction of conditioned fear. Neuropsychopharmacology 36, 529-538. doi: 10.1038/npp.2010.184

Sigmund, J. C., Vogler, C., Huynh, K. D., De Quervain, D. J., and Papassotiropoulos, A. (2008). Fine-mapping at the HTR2A locus reveals multiple episodic memory-related variants. Biol. Psychol. 79, 239-242. doi: 10.1016/j.biopsycho.2008.06.002

Singh, R. K., Jia, C., Garcia, F., Carrasco, G. A., Battaglia, G., and Muma, N. A. (2010). Activation of the JAK-STAT pathway by olanzapine is necessary for desensitization of serotonin2A receptor-stimulated phospholipase $\mathrm{C}$ signaling in rat frontal cortex but not serotonin $2 \mathrm{~A}$ receptor-stimulated hormone release. J. Psychopharmacol. 24, 1079-1088. doi: 10.1177/0269881109 103090

Snigdha, S., Horiguchi, M., Huang, M., Li, Z., Shahid, M., Neill, J. C., et al. (2010). Attenuation of phencyclidine-induced object recognition deficits by the combination of atypical antipsychotic drugs and pimavanserin (ACP 103), a 5hydroxytryptamine(2A) receptor inverse agonist. J. Pharmacol. Exp. Ther. 332, 622-631. doi: 10.1124/jpet.109.156349

Sparkes, R. S., Lan, N., Klisak, I., Mohandas, T., Diep, A., Kojis, T., et al. (1991). Assignment of a serotonin 5HT-2 receptor gene (HTR2) to human chromosome 13q14-q21 and mouse chromosome 14. Genomics 9, 461-465. doi: 10.1016/0888-7543(91)90411-7

Squire, L. R., Stark, C. E., and Clark, R. E. (2004). The medial temporal lobe. Annu. Rev. Neurosci. 27, 279-306. doi: 10.1146/annurev.neuro.27.070203.1 44130

Squire, L. R., Wixted, J. T., and Clark, R. E. (2007). Recognition memory and the medial temporal lobe: a new perspective. Nat. Rev. Neurosci. 8, 872-883. doi: $10.1038 / \mathrm{nrn} 2154$

Stein, C., Davidowa, H., and Albrecht, D. (2000). 5-HT(1A) receptor-mediated inhibition and 5-HT(2) as well as 5-HT(3) receptor-mediated excitation in different subdivisions of the rat amygdala. Synapse 38, 328-337. doi: 10.1002/1098-2396(20001201)38:3<328::AID-SYN12>3.0.CO;2-T

Stiedl, O., Birkenfeld, K., Palve, M., and Spiess, J. (2000). Impairment of conditioned contextual fear of $\mathrm{C} 57 \mathrm{BL} / 6 \mathrm{~J}$ mice by intracerebral injections of the NMDA receptor antagonist APV. Behav. Brain Res. 116, 157-168. doi: 10.1016/S0166-4328(00)00269-2

Strachan, R. T., Allen, J. A., Sheffler, D. J., and Roth, B. L. (2010). p90 Ribosomal S6 kinase 2, a novel GPCR kinase, is required for growth factormediated attenuation of GPCR signaling. Biochemistry 49, 2657-2671. doi: 10.1021/bi901921k

Strachan, R. T., Allen, J. A., Sheffler, D. J., Willard, B., Kinter, M., Kiselar, J. G., et al. (2009). Ribosomal S6 kinase 2 directly phosphorylates the 5-hydroxytryptamine 2A (5-HT2A) serotonin receptor, thereby modulating 5-HT2A signaling. J. Biol. Chem. 284, 5557-5573. doi: 10.1074/jbc.M805705200

Szapiro, G., Vianna, M. R., Mcgaugh, J. L., Medina, J. H., and Izquierdo, I. (2003). The role of NMDA glutamate receptors, PKA, MAPK, and CAMKII in the hippocampus in extinction of conditioned fear. Hippocampus 13, 53-58. doi: 10.1002/hipo.10043

Talvik-Lotfi, M., Nyberg, S., Nordstrom, A. L., Ito, H., Halldin, C., Brunner, F., et al. (2000). High 5HT2A receptor occupancy in M100907-treated schizophrenic patients. Psychopharmacology (Berl) 148, 400-403. doi: 10.1007/s0021300 50069

Thomas, E. A., Carson, M. J., Neal, M. J., and Sutcliffe, J. G. (1997). Unique allosteric regulation of 5-hydroxytryptamine receptor-mediated signal transduction by oleamide. Proc. Natl. Acad. Sci. U.S.A. 94, 14115-14119. doi: 10.1073/pnas.94.25.14115

Tovote, P., Fadok, J. P., and Luthi, A. (2015). Neuronal circuits for fear and anxiety. Nat. Rev. Neurosci. 16, 317-331. doi: 10.1038/nrn3945
Turner, J. H., and Raymond, J. R. (2005). Interaction of calmodulin with the serotonin 5-hydroxytryptamine2A receptor. A putative regulator of $\mathrm{G}$ protein coupling and receptor phosphorylation by protein kinase C. J. Biol. Chem. 280, 30741-30750. doi: 10.1074/jbc.M501696200

Uchida, S., Umeeda, H., Kitamoto, A., Masushige, S., and Kida, S. (2007). Chronic reduction in dietary tryptophan leads to a selective impairment of contextual fear memory in mice. Brain Res. 1149, 149-156. doi: 10.1016/j.brainres.2007.02.049

Vaidya, V. A., Marek, G. J., Aghajanian, G. K., and Duman, R. S. (1997). 5-HT2A receptor-mediated regulation of brain-derived neurotrophic factor mRNA in the hippocampus and the neocortex. J. Neurosci. 17, 2785-2795.

Versijpt, J., Van Laere, K. J., Dumont, F., Decoo, D., Vandecapelle, M., Santens, P., et al. (2003). Imaging of the 5-HT2A system: age-, gender-, and Alzheimer's disease-related findings. Neurobiol. Aging 24, 553-561. doi: 10.1016/S01974580(02)00137-9

Vertes, R. P. (1991). A PHA-L analysis of ascending projections of the dorsal raphe nucleus in the rat. J. Comp. Neurol. 313, 643-668. doi: 10.1002/cne.903 130409

Vertes, R. P., Fortin, W. J., and Crane, A. M. (1999). Projections of the median raphe nucleus in the rat. J. Comp. Neurol. 407, 555-582. doi: 10.1002/(SICI)1096-9861(19990517)407:4<555::AID-CNE7>3.0.CO;2-E

Vinals, X., Moreno, E., Lanfumey, L., Cordomi, A., Pastor, A., De La Torre, R., et al. (2015). Cognitive impairment induced by delta9-tetrahydrocannabinol occurs through heteromers between cannabinoid $\mathrm{CB} 1$ and serotonin 5-HT2A receptors. PLoS Biol. 13:e1002194. doi: 10.1371/journal.pbio.1 002194

Wagner, M., Schuhmacher, A., Schwab, S., Zobel, A., and Maier, W. (2008). The His452Tyr variant of the gene encoding the 5-HT2A receptor is specifically associated with consolidation of episodic memory in humans. Int. J. Neuropsychopharmacol. 11, 1163-1167. doi: 10.1017/S1461145708 00905X

Walker, D. L., Ressler, K. J., Lu, K. T., and Davis, M. (2002). Facilitation of conditioned fear extinction by systemic administration or intra-amygdala infusions of $\mathrm{D}$-cycloserine as assessed with fear-potentiated startle in rats. J. Neurosci. 22, 2343-2351.

Watts, S. W. (1998). Activation of the mitogen-activated protein kinase pathway via the 5-HT2A receptor. Ann. N. Y. Acad. Sci. 861, 162-168. doi: 10.1111/j.17496632.1998.tb10187.x

Welsh, S. E., Romano, A. G., and Harvey, J. A. (1998). Effects of serotonin $5-\mathrm{HT}(2 \mathrm{~A} / 2 \mathrm{C})$ antagonists on associative learning in the rabbit. Psychopharmacology (Berl) 137, 157-163. doi: 10.1007/s002130050605

Williams, G. V., Rao, S. G., and Goldman-Rakic, P. S. (2002). The physiological role of 5-HT2A receptors in working memory. J. Neurosci. 22, 2843-2854.

Willins, D. L., Deutch, A. Y., and Roth, B. L. (1997). Serotonin 5-HT2A receptors are expressed on pyramidal cells and interneurons in the rat cortex. Synapse 27, 79-82. doi: 10.1002/(SICI) 1098-2396(199709)27:1<79::AID-SYN8>3.0. $\mathrm{CO} ; 2-\mathrm{A}$

Wiltgen, B. J., Sanders, M. J., Anagnostaras, S. G., Sage, J. R., and Fanselow, M. S. (2006). Context fear learning in the absence of the hippocampus. J. Neurosci. 26, 5484-5491. doi: 10.1523/JNEUROSCI.2685-05.2006

Xia, Z., Gray, J. A., Compton-Toth, B. A., and Roth, B. L. (2003). A direct interaction of PSD-95 with 5-HT2A serotonin receptors regulates receptor trafficking and signal transduction. J. Biol. Chem. 278, 21901-21908. doi: 10.1074/jbc.M301905200

$\mathrm{Xu}, \mathrm{T}$., and Pandey, S. C. (2000). Cellular localization of $\operatorname{serotonin}(2 \mathrm{~A})(5 \mathrm{HT}(2 \mathrm{~A}))$ receptors in the rat brain. Brain Res. Bull. 51, 499-505. doi: 10.1016/S03619230(99)00278-6

Yoshida, H., Kanamaru, C., Ohtani, A., Li, F., Senzaki, K., and Shiga, T. (2011). Subtype specific roles of serotonin receptors in the spine formation of cortical neurons in vitro. Neurosci. Res. 71, 311-314. doi: 10.1016/j.neures.2011. 07.1824

Zaniewska, M., Mccreary, A. C., Wydra, K., and Filip, M. (2010). Differential effects of serotonin (5-HT)2 receptor-targeting ligands on locomotor responses to nicotine-repeated treatment. Synapse 64, 511-519. doi: 10.1002/syn. 20756 
Zayara, A. E., Mciver, G., Valdivia, P. N., Lominac, K. D., Mccreary, A. C., and Szumlinski, K. K. (2011). Blockade of nucleus accumbens 5-HT2A and 5HT2C receptors prevents the expression of cocaine-induced behavioral and neurochemical sensitization in rats. Psychopharmacology (Berl) 213, 321-335. doi: 10.1007/s00213-010-1996-3

Zelikowsky, M., Hersman, S., Chawla, M. K., Barnes, C. A., and Fanselow, M. S. (2014). Neuronal ensembles in amygdala, hippocampus, and prefrontal cortex track differential components of contextual fear. J. Neurosci. 34, 8462-8466. doi: 10.1523/JNEUROSCI.3624-13.2014

Zhang, G., Ásgeirsdóttir, H. N., Cohen, S. J., Munchow, A. H., Barrera, M. P., and Stackman, R. W. Jr. (2013). Stimulation of serotonin 2A receptors facilitates consolidation and extinction of fear memory in C57BL/6J mice. Neuropharmacology 64, 403-413. doi: 10.1016/j.neuropharm.2012.06.007

Zhang, G., Cinalli, D., Barrera, M. P., and Stackman, R. W. (2015). “Activation of serotonin 5-HT2A receptor delays the retrieval of spatial memory in a Morriswater maze task," in Proceedings of the Society of Neuroscience Conference, Chicago.
Zhou, F. M., and Hablitz, J. J. (1999). Activation of serotonin receptors modulates synaptic transmission in rat cerebral cortex. J. Neurophysiol. 82, 2989-2999.

Zhu, B., Chen, C., Loftus, E. F., Moyzis, R. K., Dong, Q., and Lin, C. (2013). True but not false memories are associated with the HTR2A gene. Neurobiol. Learn Mem. 106, 204-209. doi: 10.1016/j.nlm.2013.09.004

Conflict of Interest Statement: The authors declare that the research was conducted in the absence of any commercial or financial relationships that could be construed as a potential conflict of interest.

Copyright (c) 2015 Zhang and Stackman. This is an open-access article distributed under the terms of the Creative Commons Attribution License (CC BY). The use, distribution or reproduction in other forums is permitted, provided the original author(s) or licensor are credited and that the original publication in this journal is cited, in accordance with accepted academic practice. No use, distribution or reproduction is permitted which does not comply with these terms. 